United States Department of the Interior

Geological Survey

\title{
HEAT FLOW IN RELATION TO HYDROTHERMAL ACTIVITY IN THE SOUTHERN BLACK ROCK DESERT, NEVADA
}

by

J. H. Sass, Mary Lou Zoback, and S. P. Galanis, Jr.

\section{Open-File Report 79-1467}

1979

This report is preliminary and has not been edited or reviewed for conformity with Geological Survey standards and nomenclature. 
Contents

page

Abstract

Introduction

Acknowledgments

Geologic setting

Heat-flow data

Sunmary of geophysical investigations

Discussion and conclusions 25

References

Appendix 


\section{Figures}

page

Fig. 1. Generalized map of heat flow and physiographic provinces in the western U.S.

Fig. 2. Geologic map of the Southern Black Rock Desert and adjoining ranges

Fig. 3. Temperature profiles, USGS wells GRA through GRZ, Black Rock Desert

Fig. 4. Thermal conductivities measured in situ in the southern Black Rock Desert

Fig. 5. Geologic map of Gerlach thermal area showing location of hot springs and test holes

Fig. 6. Termerature profiles from Cordero test wells (GE1-3), GRZ and DHI5, all in the Gerlach area 14

Fig. 7. Temperature profiles from USGS test wells in the Gerlach area

Fig. 8. Temperature profiles for Cordero holes near Fly Ranch KGRA -..... 18

Fig. 9. Temperature profiles for USGS test wells near Fly Ranch

Fig. 10. Heat-flow contours (in HFU), southern Black Rock Desert

Fig. 11. Depth to basement in the southern Black Rock Desert and Hualapai Flat

Fig. Al. Sun Oil, BRI and BR2

Fig. A2. Black Rock Desert, GRL

Fig. A3. PMS -

Fig. A4. Sun 0il, FY 36

Fig. A5. Sum 0il, GEI and GE3 37

Fig. A6. Sun Oil, GE2 38 


\section{Tables}

page

Table 1. Locations, temperature gradients, thermal conductivities, and heat flows for holes in the southern Black Rock

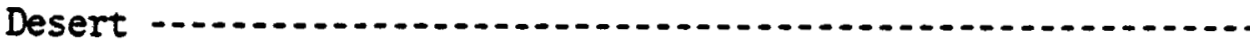

Table 2. Locations, conductive temperature gradients, lithology, and estimated heat flows for holes near the Gerlach geothermal area

Table 3. Locations, conductive temperature gradients, 1ithology, and estimated heat flows for holes near the

Fly Ranch geothermal area

Table 4. Heat discharge of hot springs in the southern Black Rock Desert . 27

Table Al. Estimates of spring discharge from the southern Black Rock Desert ....... 39 


\section{ABSTRACT}

As part of an investigation of the Gerlach NE KGRA ("Known Geothermal Resource Area") a number of heat-flow measurements were made in playa sediments of the southern Black Rock Desert, northwestern Nevada. These data together with additional previously unpublished heat-flow values reveal a complex pattern of heat flow with values ranging between 1.0-5.0 HFU (40-100 $\mathrm{mWm}^{-2}$ ) outside of the hot springs area. The mean heat flow for the 13 reported sites in the southern Black Rock Desert is $1.8 \pm 0.15 \mathrm{HFU}\left(75 \pm 6 \mathrm{mWm}^{-2}\right)$.

The complexity of the pattern of heat flow is believed to arise from hydrothermal circulation supporting the numerous hot springs throughout the region. The fact that the lowest observed heat flow occurs in the deepest part of the basin strongly suggests that fluid movement within the basin represents part of the recharge for the hydrothermal system. Hence the heat-flow data do not support a "thermal blanketing" model to explain the geothermal activity. The nature of the modern activity is believed to be related to deep circulation of meteoric water. Such deep circulation and subsequent upwelling along range-front faults is typical of geothermal systems throughout the Basin and Range province. Microearthquake activity indicates active fracturing to the required depths of circulation $(4-7 \mathrm{~km})$.

A thermal balance for the system incorporating both anomalous conductive heat loss and convective heat loss from the spring systems indicate a total energy loss of about $8.0 \mathrm{Mcal} / \mathrm{sec}$ or 34 megawatts over an estimated $1000 \mathrm{~km}^{2}$ region. Consideration of this additional heat loss yields a mean regional heat Now of $2.5+$ HFU $\left(100+\mathrm{mWm}^{-2}\right)$ and warrants inclusion of this region in the Battle Mountain heat-now high (Lachenbruch and Sass, 1977, 1978). 


\section{INTRODUCTION}

Hydrothermal activity occurs at many locations along the margins of the Black Rock Desert in northern Nevada (Waring, 1965; Renner and others, 1975; Brook and others, 1979). The geothermal potential of the region has been scrutinized by both industry and Government agencies, and it has been the subject of a concerted geological and geophysical study by faculty and students of the Colorado School of Mines. The results of the latter study recently have been summarized in Colorado School of Mines Quarterly, v. 73, nos. 3 and 4, edited by G. V. Keller and L. T. Grose. On the basis of high thermal gradients in wells, high heat flow in contiguous regions, and the observed hydrothermal activity, Lachenbruch and Sass (1977, 1978) have included the southern Black Rock Desert within the Battle Mountain heat-flow high (BMH, Figure 1; see also map \#1 of Muffler, 1979).

In September 1978, 13 holes (GRA through GRL and GRZ) were drilled in the southern Black Rock Desert, primarily to provide a regional heat-flow context for evaluation of the Gerlach NE "Known Geothermal Resources Area" (RGRA) (Figure 2). The holes also were used for the first comprehensive field trials of the USGS downhole heat-now probe (Sass and others, 1979). In addition to the holes drilled for the KGRA study, we present the results from a hole drilled in granite for regional heat-flow studies (PMS, Figure 2), and some hitherto unpublished results from holes drilled by the Cordero Mining Company in 1972. We also present and re-examine temperature profiles obtained by Olmsted and others (1975) in the Gerlach and Fly Ranch KGRA's. 


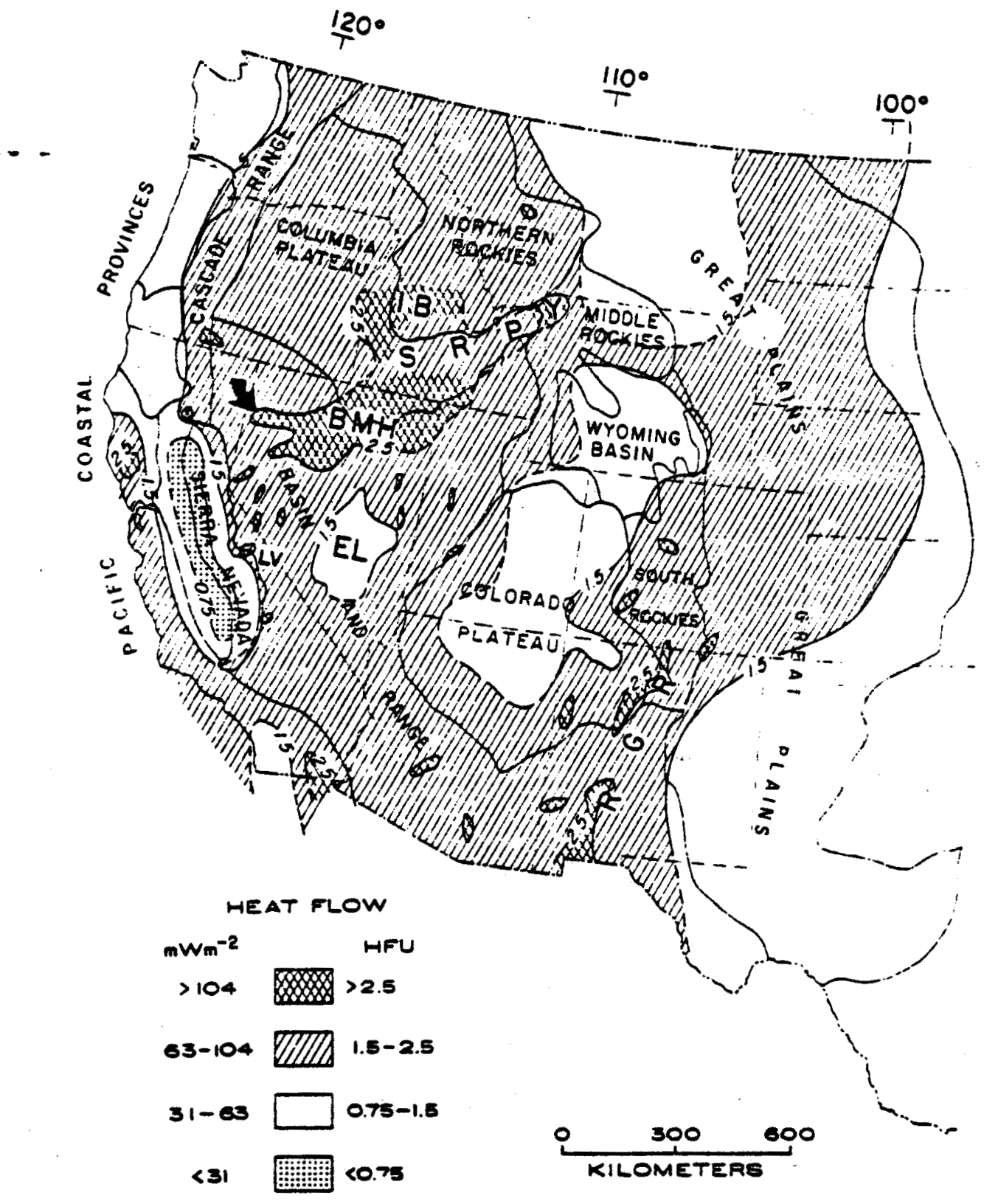

Figure 1. Generalized map of heat flow and physiographic provinces in the westem U.S. (after Lachenbruch and Sass, 1978; Lachenbruch, 1978). Abbreviations are BM, Battle Mountain High; SRP, Snake River Plain; IB, Idaho Batholith; Y, Yellowstone; RGR, Rio Grande Rift; El, Eureka Low; LV, Long Valley. Arrow indicates present study area. 


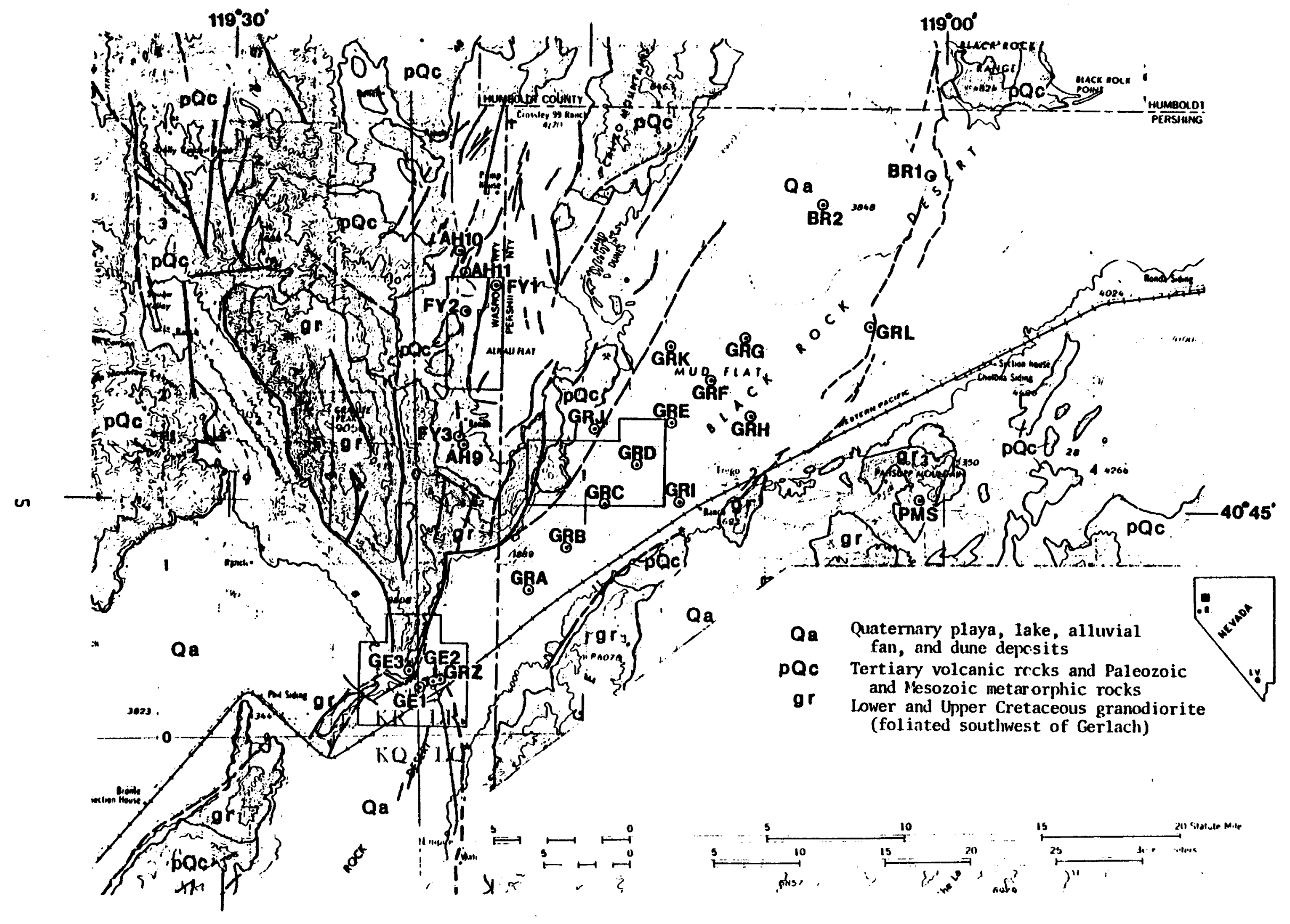

Figure 2. Geologic map of the southern Black Rock Desert and adjoining ranges (after Wi11den, 1964; Bonham, 1969; 01msted and others, 1975; Grose and Sperandio, 1978). Also outlined are the (ierlach (CI:), F1y Ranch (FY), and Gerlach NE (GR) KCRA's. 
The following units are used frequently in the remainder of this report: Temperature ${ }^{\circ} \mathrm{C}$

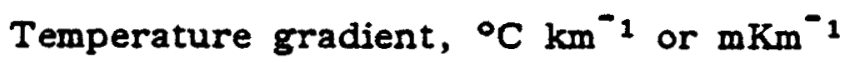

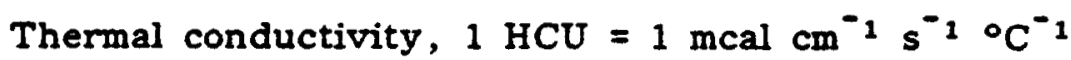

$$
=0.418 \mathrm{Wm}^{-1} \mathrm{~K}^{-1}
$$

Heat flow, $1 \mathrm{HFU}=10^{-6} \mathrm{cal} \mathrm{cm}^{-2} \mathrm{~s}^{-1}=41.8 \mathrm{mWm}^{-2}$

In addition to latitude and longitude, the USGS Water Resources Division convention is used to specify site locations, i.e., $32 / 38-26 \mathrm{bba}$ represents $N E^{\frac{1}{4}}, N W^{\frac{1}{4}}, N W^{\frac{2}{4}}, T 32 N, R 38 E$, sec 26.

Acknowledgments. We thank Frank Olmsted for allowing us to present his heretofore unpublished temperature profiles for the Gerlach area and for his constructive criticism of an early draft of the report. Rebecca Dodge and Trowbridge Grose kindly allowed us to reproduce their unpublished map of the Black Rock fault. We are grateful to Jack. Kennelly, Walt Wendt, Tom Moses, Vaughn Marshall, and Gene Smith for assistance in the field. Bruno Selmi granted us permission to drill well GRZ on his property. 


\section{GEOLOGIC SETTING}

Ranges surrounding the southern Black Rock Desert (Figure 2) are composed largely of Cretaceous granodiorite, Permo-Triassic metavolcanic and metasedimentary rocks, and Late Oligocene-early Miocene rhyolitic, andesitic, and basaltic sequences (Grose and Sperandio, 1978; Bonham, 1969; Wilden, 1964). Valley fill includes Pliocene(?) and Quaternary alluvial and lacustrine sediments. The youngest volcanism in the region is basaltic and has been dated at $23 \mathrm{~m} . \mathrm{y}$. (Grose and Sperandio, 1978). The nature and age of this volcanism appears to preclude its being related to the heat source for the modern hydrothermal activity.

The southern Black Rock Desert region is a site of currently active tectonism marked by abundant late Pleistocene and Holocene faults. The major hot springs in the area, Gerlach, Mud, Trego, and Fly Ranch, occur on or very near faults with Quaternary displacements. Surficial tension cracks (interpreted as tectonic in origin), fault patterns, and seismic focal mechanisms indicate active tectonic spreading along a west-northwest--eastsoutheast axis in the Gerlach region (Grose, 1978, and Kumamoto, 1978). This pattern of deformation is consistent with a relatively uniform WNW-ESE extension direction throughout northern Nevada (Zoback and Thompson, 1978). 


\section{HEAT-FLOW DATA}

Southern Black Rock Desert. For the 13 holes drilled specifically for the KGRA study (GRA through GRZ, Figure 2), thermal conductivity data were obtained at two or more depths within the hole and used to calculate heat flow (see Appendix B, Sass and others, 1979, for details). The most recent temperature profiles from all of these holes aré shown in Figure 3 . In common with other areas within and near hydrothermal systems (e.g., Lachenbruch and others, 1976), three distinct categories of profile are observed. The upper $40 \mathrm{~m}$ of GRB and GRC indicate recharge (or at least a downward vertical component of water movement). Except for GRZ, the remainder of the profiles indicate heat transfer primarily by conduction with a modal and average value of about $75^{\circ} \mathrm{C} / \mathrm{km}$ for the temperature gradient. GRZ was flowing vigorously during drilling and $63^{\text {sacks }}$ of cement were required to stop the flow of water from the annulus upon completion of the hole. The temperature profile (Figure 3) has pronounced curvature below a depth of $20 \mathrm{~m}$, indicating vigorous vertical water movement. Above $20 \mathrm{~m}$ the curvature is quite small, indicating that heat is being transferred primarily by conduction in the near-surface zone.

Heat-flow calculations for the Black Rock Desert (exclusive of the Gerlach GGRA) are summarized in Table 1. Heat Nows range from 1.0 to $5 \mathrm{HFU}$ (40 to $200 \mathrm{mWm}^{-2}$ ) but most are below that (2.5 HFU) characteristic of the Battle Mountain high. In fact, on this reconnaissance scale ( $\sim 3 \mathrm{~km}$ centers), the Gerlach NE "KGRA" (Figure 2) and its immediate environs are characterized by lower than average heat now for the Basin and Range province.

The distribution of thermal conductivity is bimodal with peaks at about 2.25 and 2.75 HCU (Figure 4), the higher conductivities probably reflecting higher proportions of sand. It is worth noting, however (Table 1), that the 


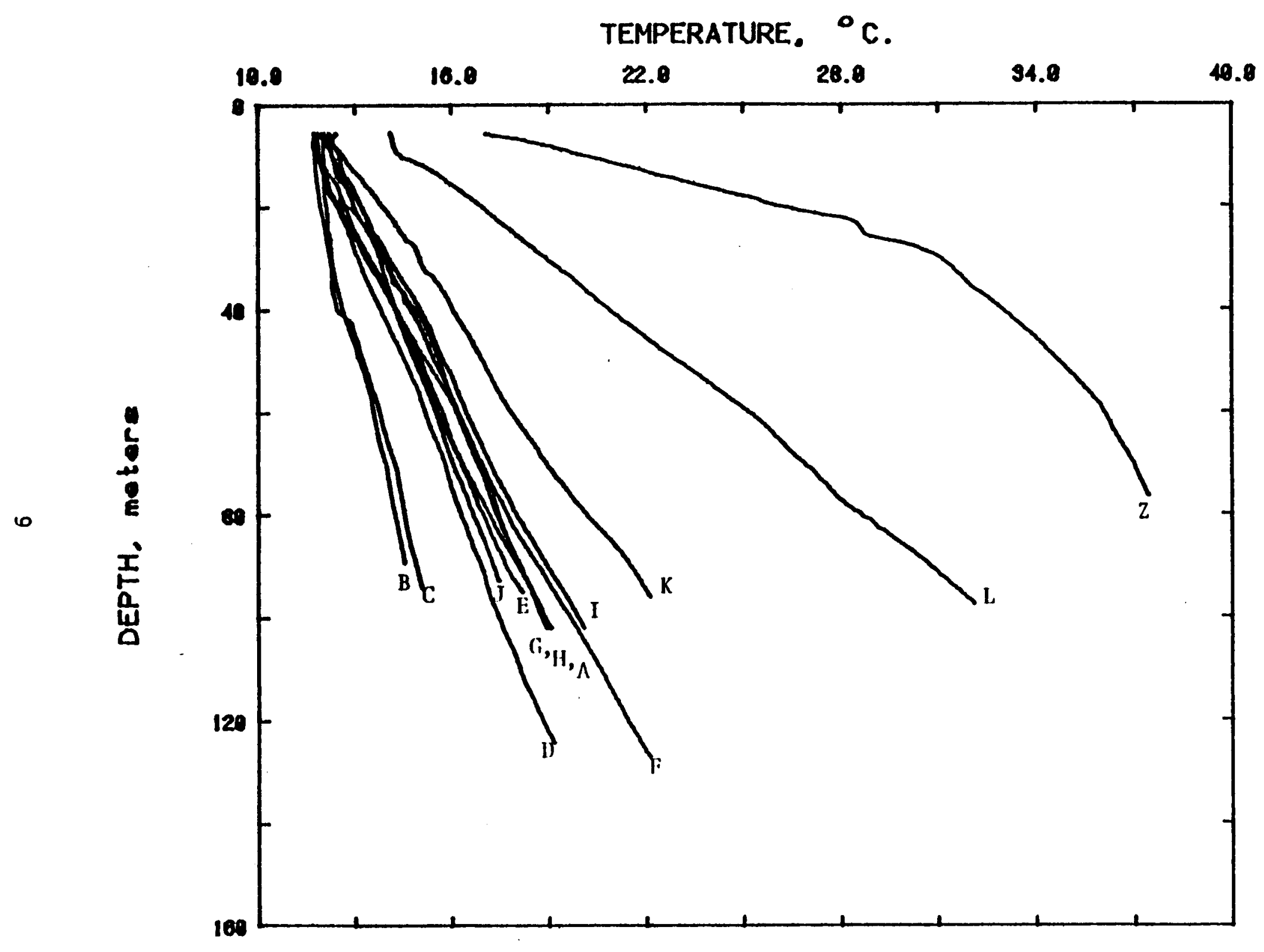

Figure 3. Temperature profiles, USCS wells GRA through GRZ, Black Rock Desert. The wells were drilled in September 1978, and the profiles shown were obtained in December 1978. 
TABL: 1. Locations, temerature gradients, thermil conhuctivities, and heat flows for holes in the southern llack Rock lesert

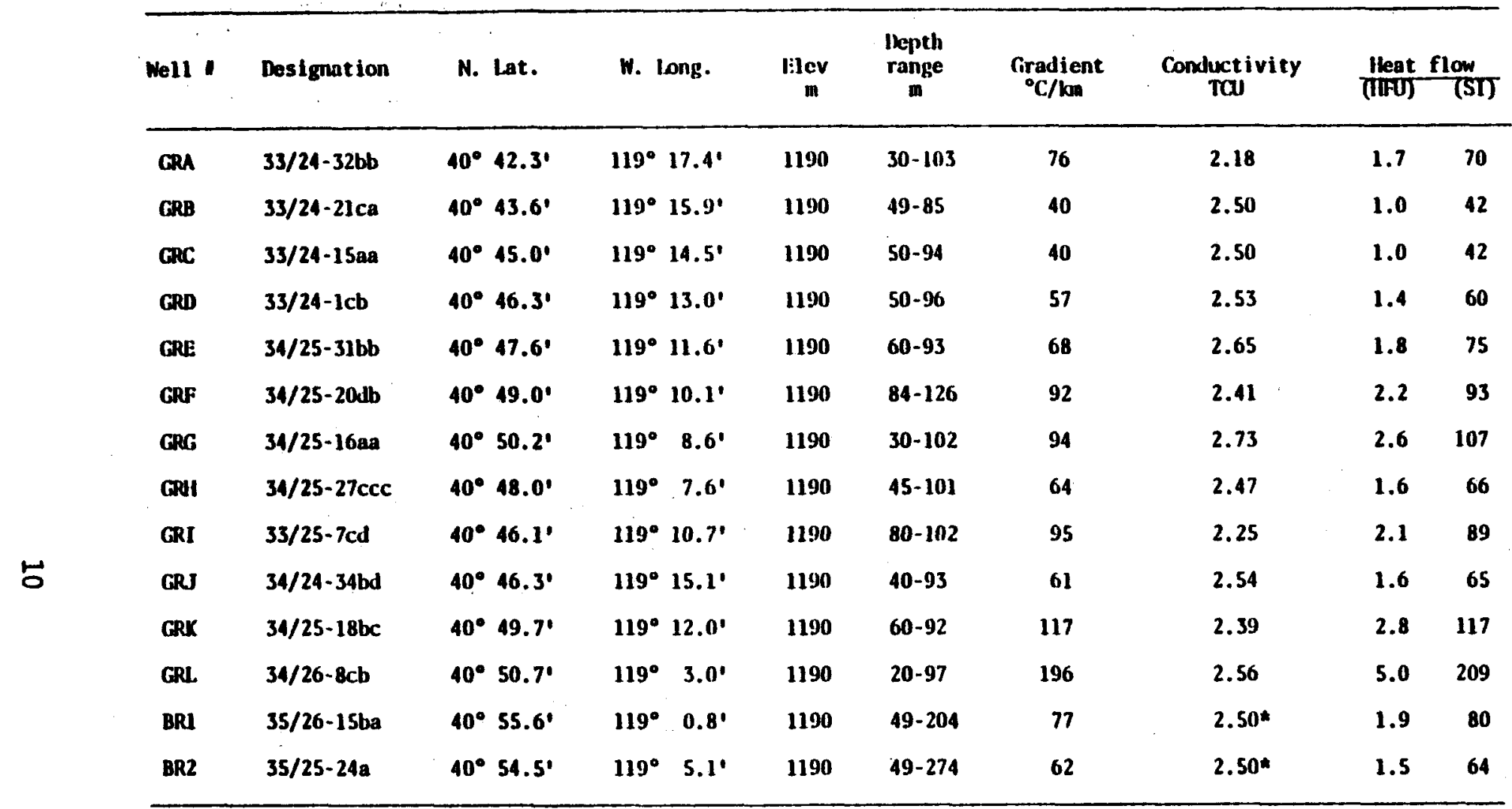

"Average conductivity from downhole experinents (see figure 4). 


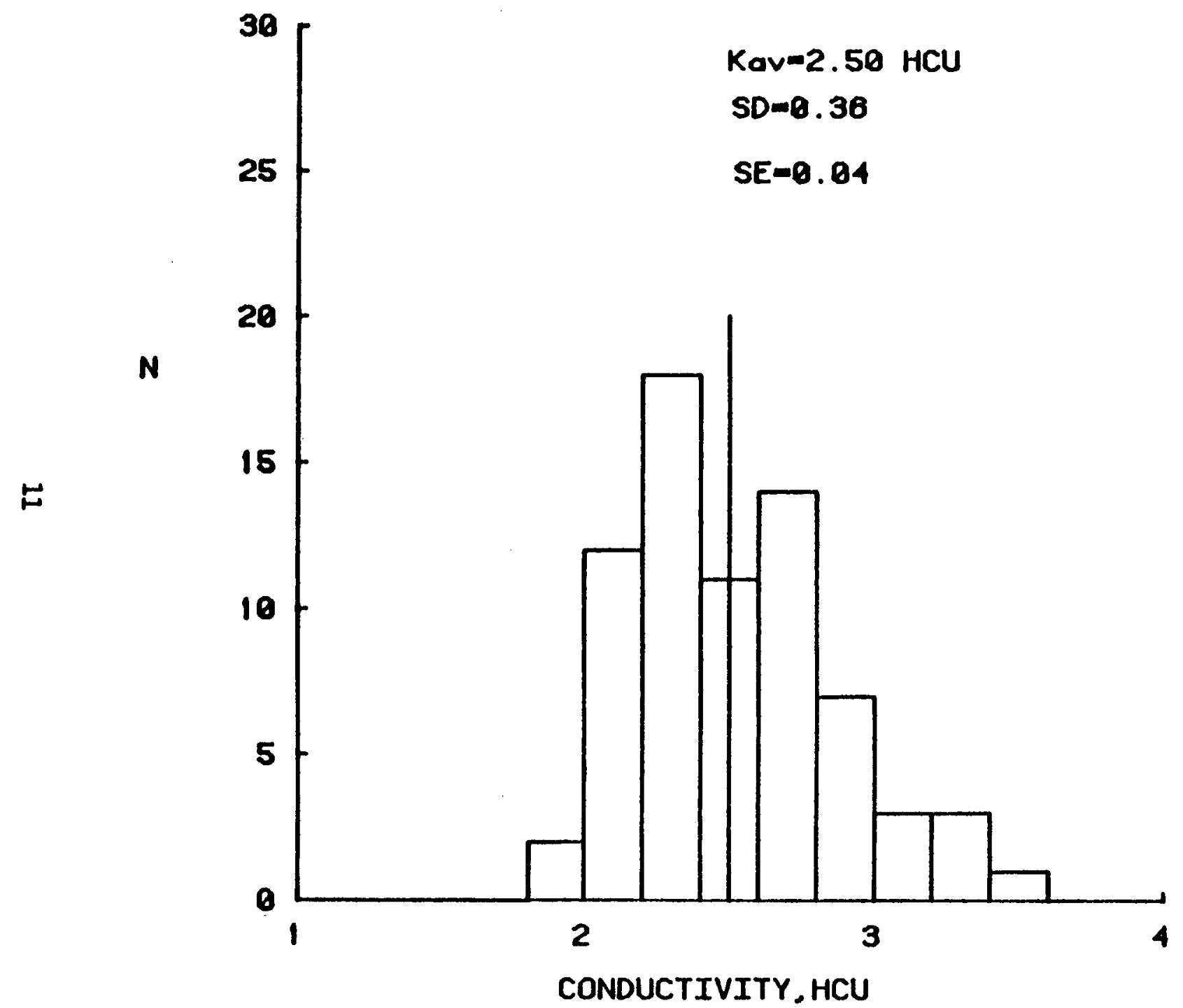

Figure 4. Thermal conductivities measured in situ in the southem Black Rock Desert (see Appendix B, Sass and others, 1979) 
mean conductivity of every hole is within one standard deviation from the mean for the entire study area. Thus we feel justified in using the mean conductivity of $2.5 \mathrm{HCU}\left(1.05 \mathrm{Wm}^{-1} \mathrm{~K}^{-1}\right)$ to estimate heat flow from BR1 and BR2 (Figure 2 and Figure A-1, Appendix A).

Gerlach KGRA. Figure 5 shows the locations of all test wells within the Gerlach KGRA (Figure 2) in relation to the major structural features and hot springs. Temperature profiles for the deepest and hottest wells are presented in Figure 6 and for the remainder in Figure 7.

Even though few of these profiles represent pure conduction (Table 2), it is instructive to calculate heat flows for the conductive portions of the profiles. For the unconsolidated materials, the mean of $2.5 \mathrm{HCU}$ (Figure 4) was used again. This seems reasonable in view of the mean value of $2.6 \mathrm{HCU}$ cited by Olmsted and others (1975). The heat-flow values (Table 2 and Figure 5) are variable and generally high, as we might expect from such an area. Although the control is sketchy, the area of elevated heat flow (>2 HFU) seems fairly small $\left(\sim 20 \mathrm{~km}^{2}\right.$ ) (cf. Figure 24 and Table 13 of Olmsted and others, 1975). On the basis of the contours of Figure 5, the total conductive heat loss from the anomalous zone is about $4 \times 10^{6} \mathrm{cal} \mathrm{s}^{-1}$ ( $17 \mathrm{MW}$ ) which compares favorably with the preferred estimate of $4.4 \times 10^{6} \mathrm{cal} \mathrm{s}^{-1}$ ("Method $\left.B^{n}\right)$ of Olmsted and others, who also estimated a convective discharge of about $1.4 \times 10^{6} \mathrm{cal} \mathrm{s}^{-1}$, about one-third of the anomalous conductive flux.

The heat flow of 2.5 HFU from the lowermost 85 meters of GE2 might represent the regional conductive heat flux beneath the shallow hydrothermal system, but it could just as easily reflect a thermal boundary imposed by a deeper circulation system or by lateral water flow beneath a conductive "cap." Fly Ranch - Hualapai Flat. This area contains many of the more interesting geophysical anomalies (discussed in the next section) discovered by the 


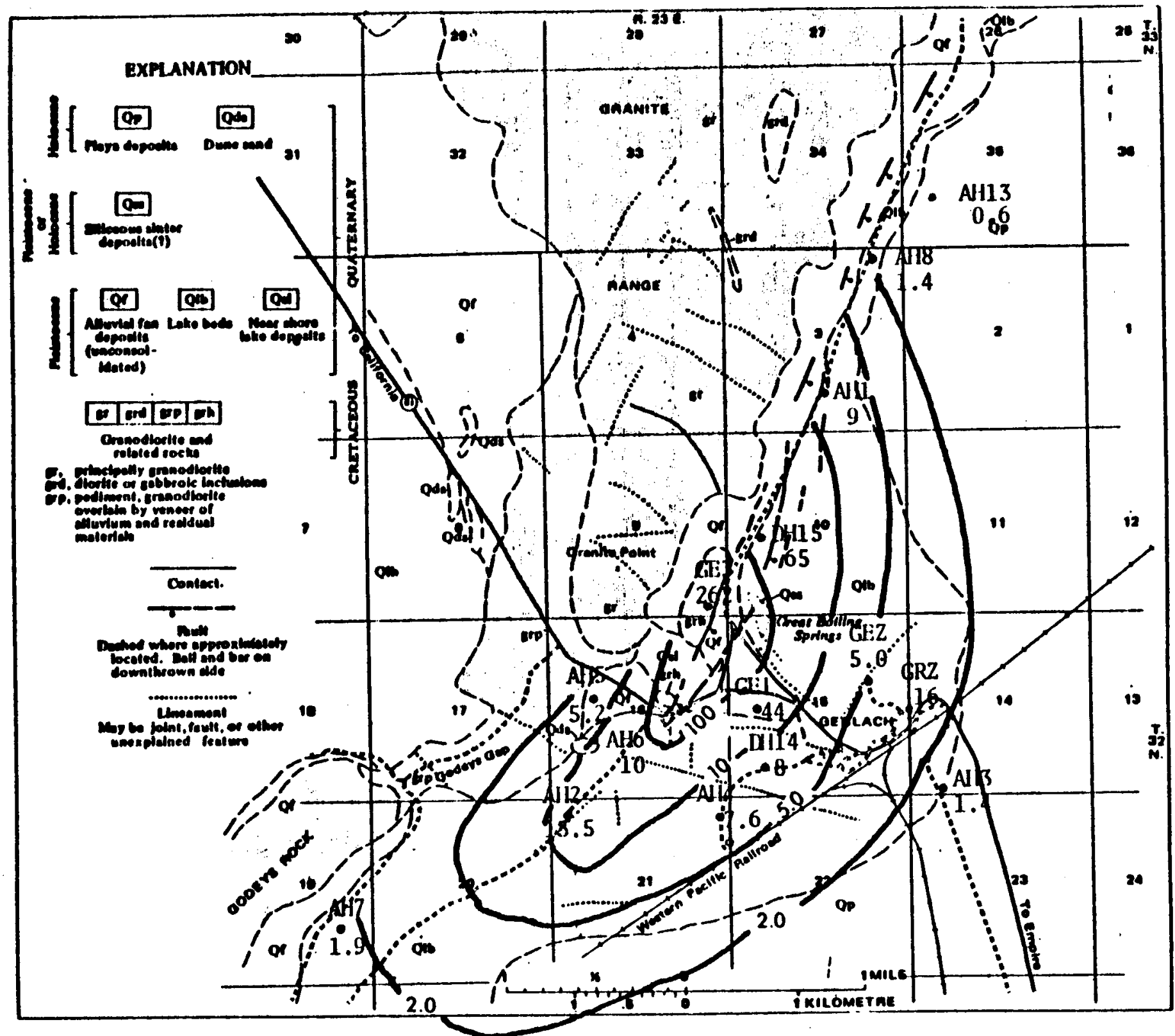

Figure 5. Geologic map of Gerlach thermal area showing location of hot springs and test holes (from Figure 19 of 0lmsted and others, 1975). Heat flows (Table 2) are given in HFU. 


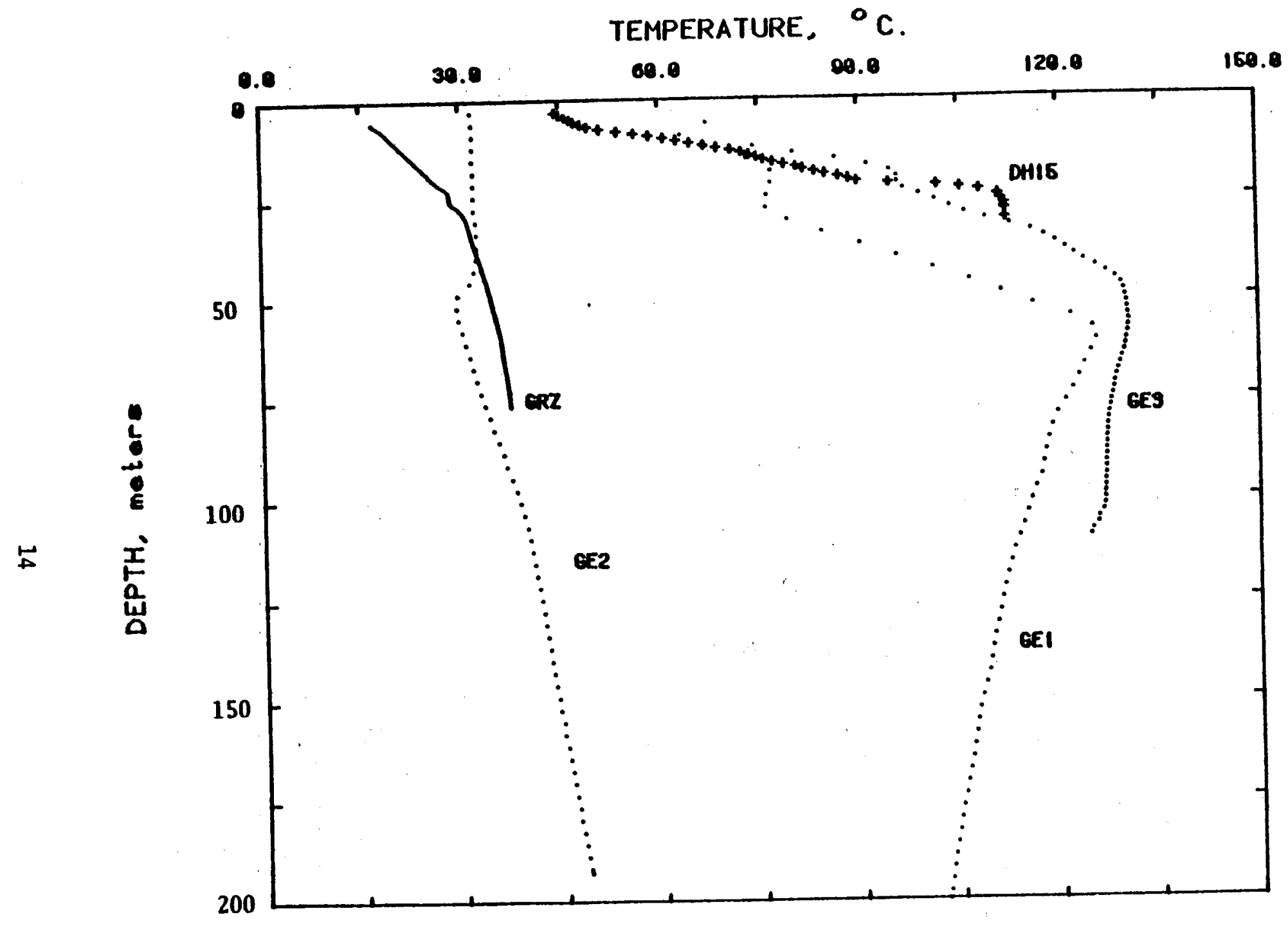

Figure 6. Temperature profiles from Cordero test wells (GE1-3), GRZ and $D H 15$, all in the Gerlach area. 


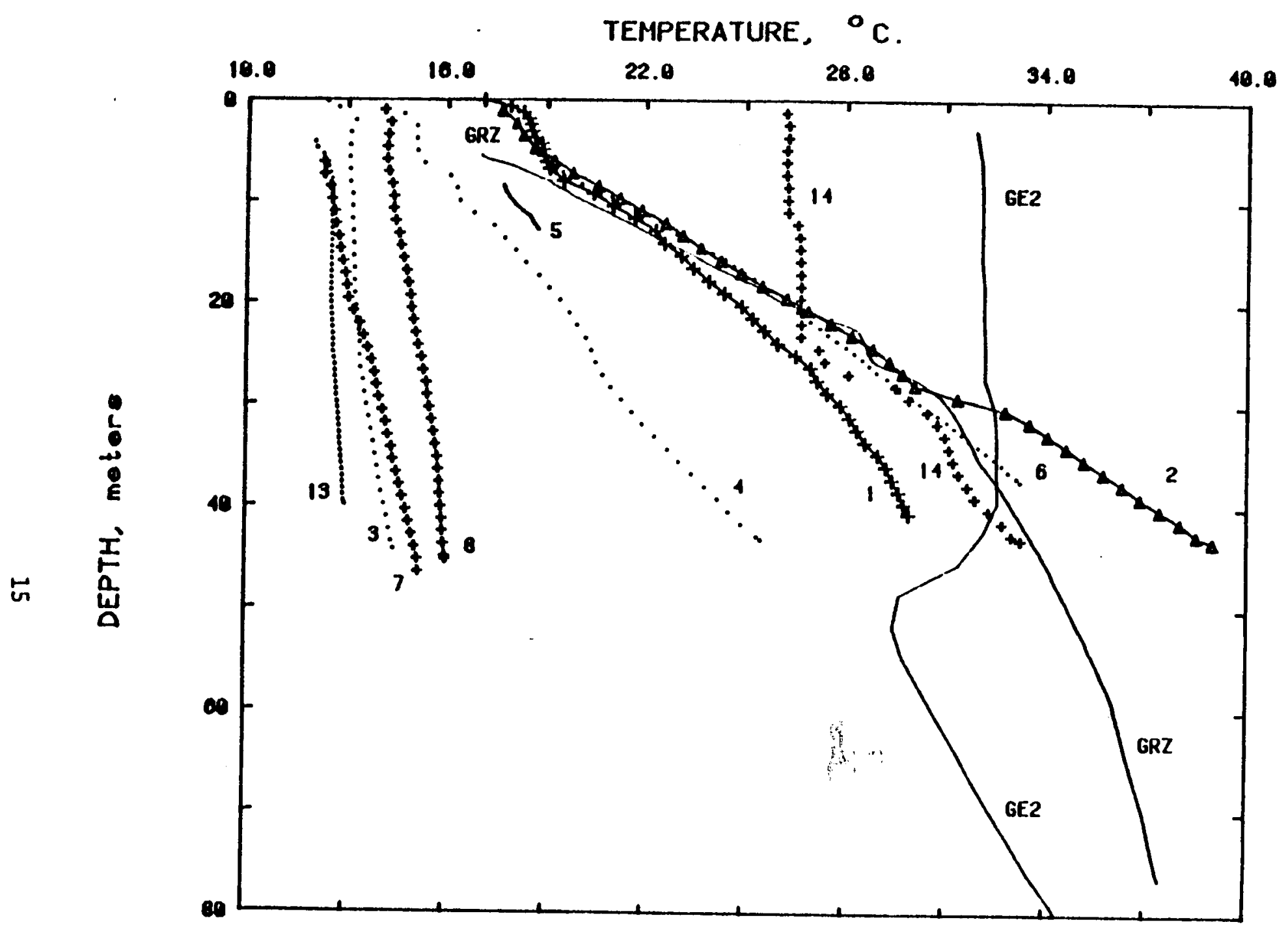

Figure 7. Temperature profiles from USGS test wells in the Gerlach area (from olmsted and others, 1975, see Figure 5 for location). Profiles from GRZ and the upper part of GE2 are presented for reference (cf., liigure 6). 
TAHIl: 2. Locations, conductive temperature gradients, lithology, and estimated heat flows for boles mear the (ierlach geothermal area

\begin{tabular}{|c|c|c|c|c|c|c|c|c|c|c|}
\hline Well 1 & Tyre' & Designation & N. Lat. & W. long & $\begin{array}{c}\text { fiev } \\
\text { nn }\end{array}$ & 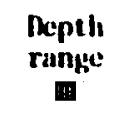 & $\begin{array}{l}\text { Gradient } \\
{ }^{\circ} \mathrm{C} / \mathrm{km}\end{array}$ & Lithology 2 & $\frac{\text { lleat }}{\text { (ाII) }}$ & $\frac{\text { flow' }}{\text { (SI) }}$ \\
\hline CE-1 & d & $32 / 23-15 c b a$ & $40^{\circ} 39.3^{\prime}$ & $119^{\circ} 22.0^{\prime}$ & 1208 & $30 \cdot 55$ & 1750 & Aluviun; $5,8, c$ & 44 & 1830 \\
\hline \multirow[t]{2}{*}{ CE-2 } & $d+c$ & $32 / 23-15 a d b$ & $40^{\circ} 39.4^{\prime}$ & $119^{\circ} 21.3^{\prime}$ & 1204 & $58-107$ & 198 & $s, c$ & 5 & 207 \\
\hline & & & & & & $107-192$ & 99 & $c, s$ & 2.5 & 104 \\
\hline CE-3 & d & $32 / 23$-gldd & $40^{\circ} 39.8^{\prime}$ & $119^{\circ} 22.3^{\circ}$ & 1230 & $12 \cdot 16$ & 3750 & Granodiorite & 262 & 11000 \\
\hline GRZ & $\mathbf{d}$ & $32 / 23-15 d a a$ & $40^{\circ} 39.2^{\prime}$ & $119^{\circ} 21.0^{\prime}$ & 1196 & $7-22$ & 623 & $c, s$ & 16 & 650 \\
\hline \multirow[t]{2}{*}{ NI-1 } & d & $32 / 23-3 \mathrm{dcb}$ & $40^{\circ} 40.8^{\prime}$ & $119^{\circ} 21.5^{\prime}$ & 1195 & $12-26$ & 354 & $s l, g, s, c$ & 9 & 370 \\
\hline & & & & & & $26-4$ & 213 & $s, s 1, c$ & 5.3 & 223 \\
\hline $\boldsymbol{N H}-\mathbf{2}$ & $d+c$ & $32 / 23-21 \mathrm{bbb}$ & $40^{\circ} 38.8^{\circ}$ & $119^{\circ} 23.2^{\circ}$ & 1198 & $10-43$ & $\$ 40$ & $s, s l ; c$ & 13.5 & 560 \\
\hline NH-3 & $\mathbf{r + c}$ & $32 / 23-14 c c d$ & $40^{\circ} 38.9^{\prime}$ & $119^{\circ} 20.8^{\circ}$ & 1193 & $28-44$ & 56 & $c, s, s l$ & 1.4 & 58 \\
\hline N1-4 & $c+d$ & 32/23-21aaa & $40^{\circ} 38.8^{\prime}$ & $119^{\circ} 22.2^{\prime}$ & 1197 & $30-43$ & 306 & $c, s, s l$ & 7.6 & 320 \\
\hline NH-S & $c(?)$ & $32 / 23-16 c a b$ & $40^{\circ} 39.4^{\prime}$ & $119^{\circ} 23.0^{\circ}$ & 1215 & $5-13$ & 210 & $5,8,51$ & 5.2 & 220 \\
\hline NH- 6 & c & $32 / 23-16 \mathrm{cac}$ & $40^{\circ} 39.1^{\prime}$ & $119^{\circ} 23.1^{\circ}$ & 1206 & $21-37$ & 406 & $c, 5,51, g$ & 10 & 424 \\
\hline AH-7 & c & $32 / 23-19$ dac & $40^{\circ} 38.3^{\prime}$ & $119^{\circ} 24.6^{\circ}$ & 1196 & $21-46$ & 74 & $s, s l, c$ & 1.9 & 77 \\
\hline \multirow[t]{2}{*}{$N 1-8$} & $c+r$ & $32 / 23-3 a a b$ & $40^{\circ} 41.5^{\circ}$ & $119^{\circ} 21.2^{\circ}$ & 1192 & $12-33$ & 55 & $c, s l, s$ & 1.4 & 58 \\
\hline & & & & & & $33-45$ & 26 & $c, s l, s$ & 0.6 & 27 \\
\hline NH-13 & $c+r$ & $33 / 23-35 \mathrm{cbd}$ & $40^{\circ} 41.7 \circ$ & $119^{\circ} 20.8^{\prime}$ & 1190 & $24-40$ & 24 & $c, s$ & 0.6 & 25 \\
\hline mi-14 & $d+c$ & $32 / 23-15 \mathrm{cca}$ & $40^{\circ} 39.0^{\prime}$ & $119^{\circ} 22.0^{\prime}$ & 1202 & $39-43$ & 320 & $c_{,} s$ & 8 & 334 \\
\hline DH -15 & $d+c$ & 32/23-10bca & $40^{\circ} 40.1^{\prime}$ & $119^{\circ} 21.9^{\prime}$ & 1211 & $9-21$ & 2600 & $c, 8, s$ & 65 & 2700 \\
\hline
\end{tabular}
'Type of temperature profile (see Figures 3,6 , and 7 ): $d=$ discharge and/or upward movement of water; c = conductive regime;
$r=$ recharge and/or dowmward movement of water.

${ }^{2} c$ - clay; $s$ = sand; sl - siltstone; $g$ - gravel or cobbles.

'ileat flow calculated using $2.5 \mathrm{~kW}\left(1.05 \mathrm{~m}^{-1} \mathrm{k}^{-1}\right)$ for unconsolidated material, 7 ind (2.93 $\left.\mathrm{wn}^{-1} \mathrm{k}^{-1}\right)$ for granoliorite. 
Colorado School of Mines (Crewdson, 1976, 1978) and is the site of considerable Late Quaternary rifting (according to Grose, 1978). Three test wells were drilled by the Cordero Mining Company and three by the USGS Water Resources Division (Olmsted and others, 1975). The locations of the holes (FY1 through FY3 and AH9 through AH11) are plotted on Figure 2 and the temperature profiles, on Figures 8 and 9 . All but one of the profiles indicate that heat flow is primarily by conduction. The exception (FY3, Figure 8) suggests a complicated convective pattern probably involving both lateral and upward flow of hot water. Data from these six holes (Table 3, Figure 10) suggest a long narrow region of elevated heat flow along the eastern margin of the Granite Range. F. H. Olmsted (written communication, 1979) suggests that additional shallow heat-flow work might reveal a much more complicated picture for this region that that suggested by Figure 10. 


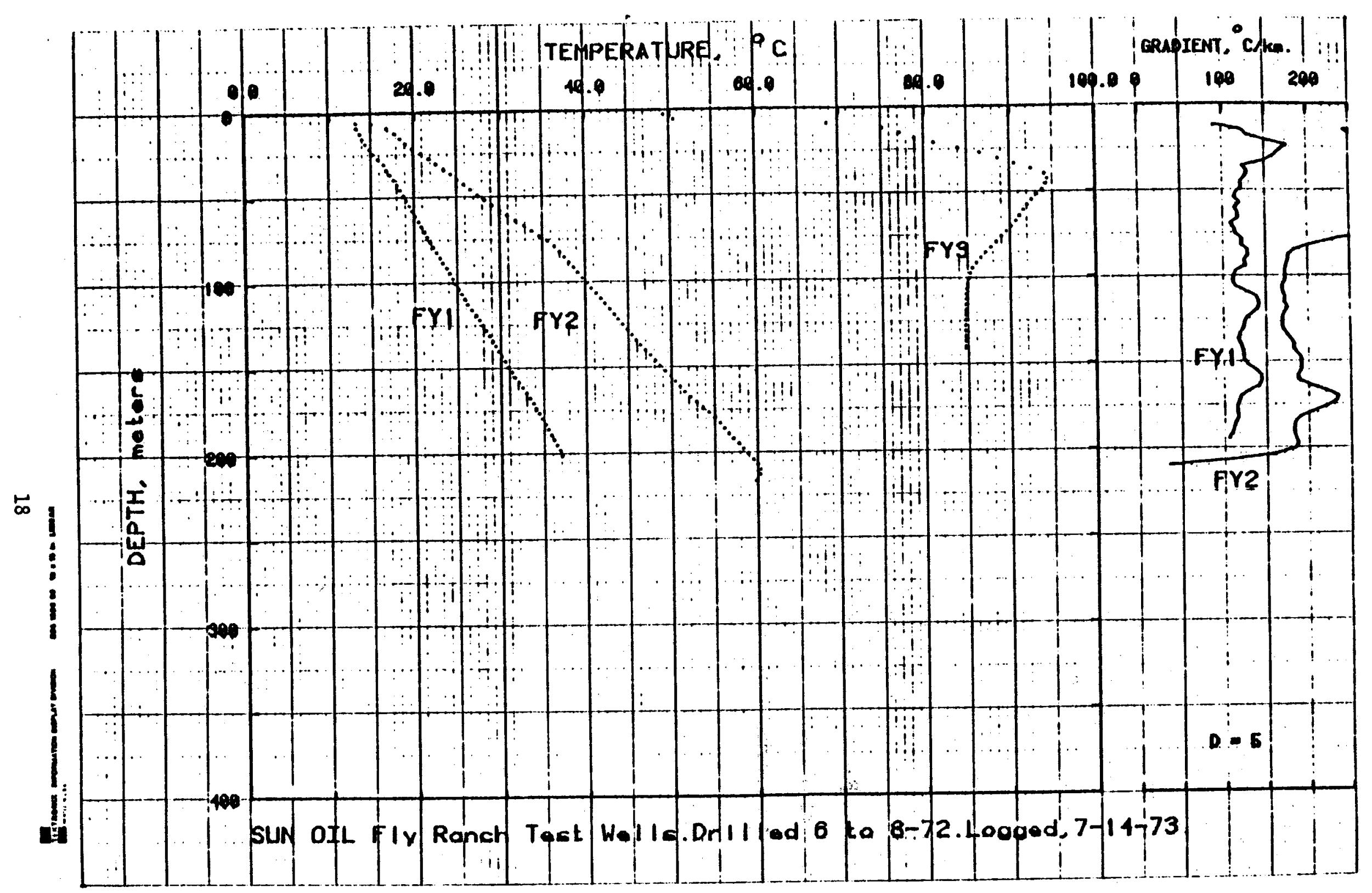

Figure 8. Temperature profiles for Cordero holes near Fly Ranch KGRA (see ligure 2 for location). 


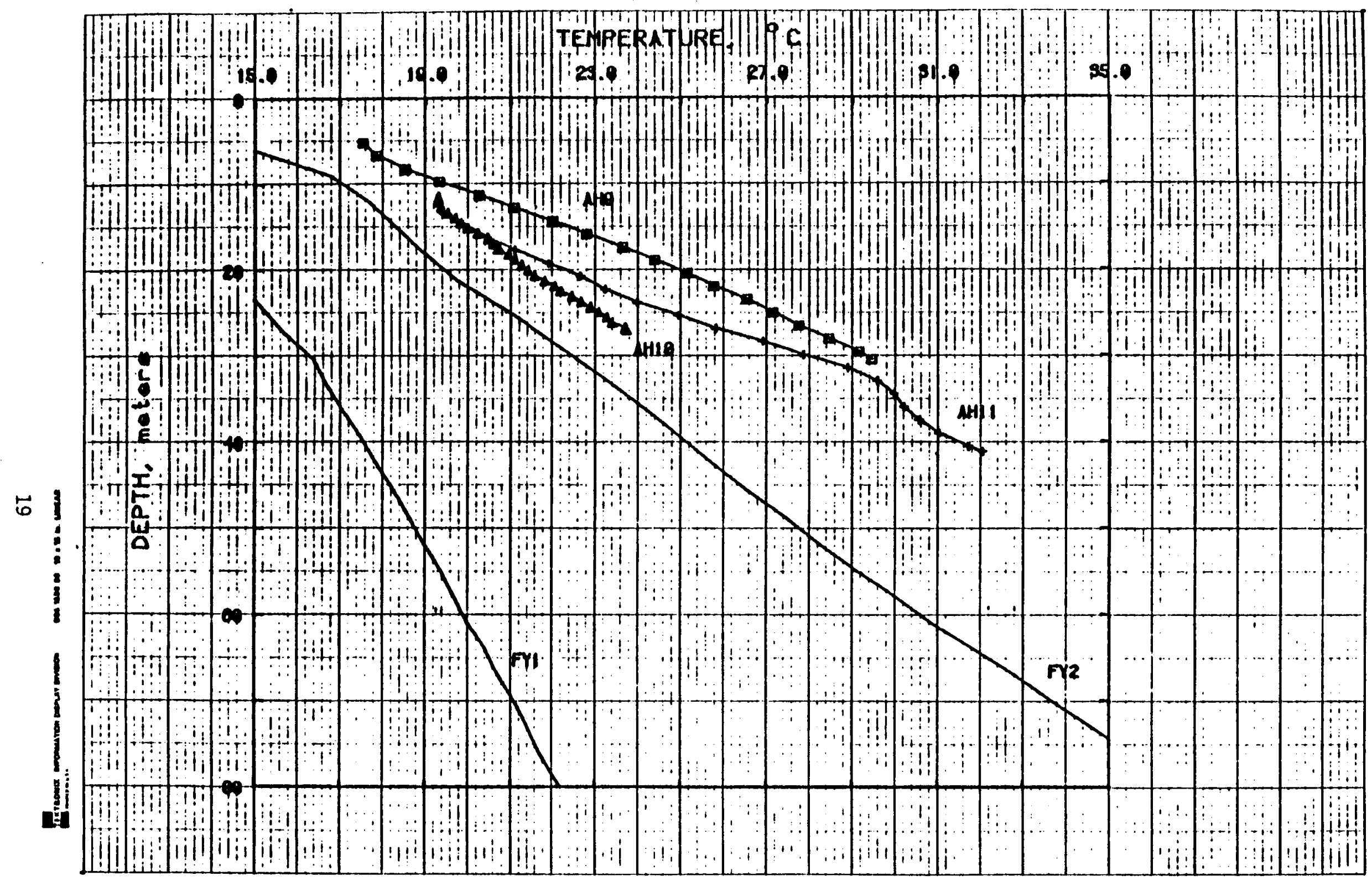

Figure 9. Temperature profiles for USGS test wells (Olnsted and others, 1979) near Fly Ranch (locations given in Figure 2). Profiles from the upper parts of Cordero FY1 and FY2 are shown for reference (cf., Figure 8). 
TABL: 3. Locations, conductive temperature gradients, lithology, and estimated heat flows for holes near the lily Rinch geothermal area

\begin{tabular}{|c|c|c|c|c|c|c|c|c|c|c|}
\hline Well " & Type' & Designation & N. Lat. & W. Long. & lilev & $\begin{array}{l}\text { Depth } \\
\text { range } \\
\text { in }\end{array}$ & $\begin{array}{l}\text { Gradient } \\
{ }^{\circ} \mathrm{C} / \mathrm{km}\end{array}$ & Lithology 2 & Heat & $\frac{\text { flow' }}{\text { (SI) }}$ \\
\hline $\mathbf{F \gamma}-1$ & $c$ & $34 / 23-1 \mathrm{adb}$ & $40^{\circ} 52.0^{\prime}$ & $119^{\circ} \quad 18.6^{\prime}$ & 1228 & $30-201$ & 123 & $s, c$ & 3.1 & 128 \\
\hline \multirow[t]{4}{*}{$\mathbf{F Y}-2$} & c & $34 / 23-11 b a a$ & $40^{\circ} 51.0^{\prime}$ & $119^{\circ} 20.0^{\circ}$ & 1243 & $8-76$ & 278 & g,c & & \\
\hline & & & & & & $76-174$ & 180 & s,ss & $6 \pm 1.5$ & $\begin{array}{l}250 \\
+60\end{array}$ \\
\hline & & & & & & $174-180$ & 230 & $\operatorname{van}$ & & \\
\hline & & & & & & $180-201$ & 183 & s,ss & & \\
\hline FY-3 & $d+c$ & $34 / 23-35 d d b$ & $40^{\circ} 47.2^{\prime}$ & $119^{\circ} 20.4^{\circ}$ & 1219 & $12-40$ & 717 & $\mathbf{s}$ & 22 & 900 \\
\hline NH-9 & c & $33 / 23-2 a$ & $40^{\circ} 46.9^{\circ}$ & $119^{\circ} 20.2^{\circ}$ & $1220(?)$ & $10-30$ & 484 & $s l, c, s$ & 12 & 500 \\
\hline NH-10 & c & $35 / 23-35 b a$ & $40^{\circ} 52.9^{\prime}$ & $119^{\circ} 20.4^{\prime}$ & 1250 & $15-27$ & 314 & $s, s l, c, g$ & 7.8 & 328 \\
\hline All-11 & $c+d$ & $35 / 23-35 \mathrm{~cd}$ & $40^{\circ} 52.3^{\circ}$ & $119^{\circ} 20.0^{\prime}$ & 1250 & $15-41$ & 460 & $c, s, s i$ & 12 & 500 \\
\hline
\end{tabular}

'Type of temperature profile (see Figures 8 and 9 ): $d=$ discharge and/or sqward water movenent; $c=c o n d u c t i v e ~ r e g i m e$.

${ }^{2} s$ - sand; $c$ - clay $(k=2.5 \mathrm{llau}) ; \mathrm{g}$ - gravel or cobbles; ss - sandstone; sl - silt; van = vesicular andesite.

"Heat flow calculated using a conductivity of 2.5 or 3 , depending on the relative proportions of sand and clay. 


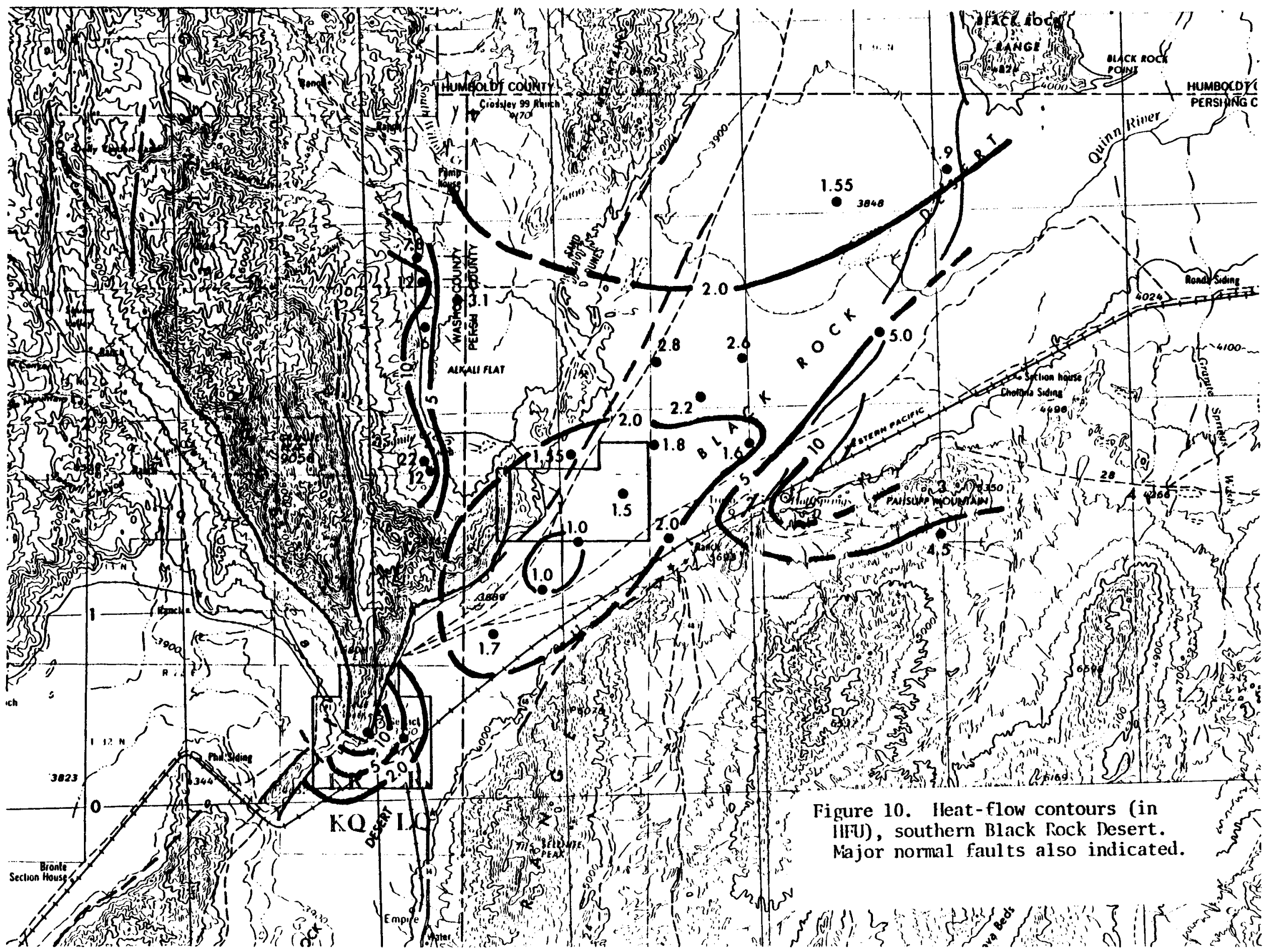




\section{SUMMARY OF GEOPHYSICAL INVESTIGATIONS}

A detailed gravity survey was conducted in Hualapi flat and the southern Black Rock Desert by Crewdson (1976, 1978). A two-dimensional constantdensity inversion of the gravity data yielded depth-to-basement estimates along numerous profiles throughout the region. A contoured depth-to-basement map based on this profile control is shown in Figure 11. The maximum valley-fill thickness along the axis of the southern Black Rock Desert is about 3,000 feet except just northeast of the town of Gerlach where depth to basement exceeds 5,000 feet. Maximum fill thickness in Hualapi flat is over 2,000 feet. The contours in the southern Black Rock Desert indicate a steep gradient in basement surface along the southeastern margin of the Granite Range, suggestive of a single, "master" fault bounding the range. However, on the opposite side of the basin (along the northeastern end of the Selenite Range) the depth-to-basement contours are much more gradual suggesting that step faulting is responsible for the downdropping of the basin in this region.

One of the gravity profiles is colinear with a seismic reflection line (Callaway, 1978). Along this line, there is an excellent agreement between the seismically inferred depths to basement and the results of the gravity inversion, indicating that the density contrast used $\left(0.67 \mathrm{~g} / \mathrm{cm}^{3}\right)$ was a true average.

A microearthquake survey run in the region for 30 days by Kumamoto (1978) detected a swarm of events which lasted for 18 hours. These events occurred in a localized ( 3 by $3 \mathrm{~km}$ in plan) zone $3-7 \mathrm{~km}$ deep along the margins of the horst block that separates Hualapi flat and the southern Black Rock Desert. Active fracturing associated with these microearthquakes supports the existence of open channelways to inferred reservoir depths of thermal springs in the region (see discussion in the next section). Analysis 


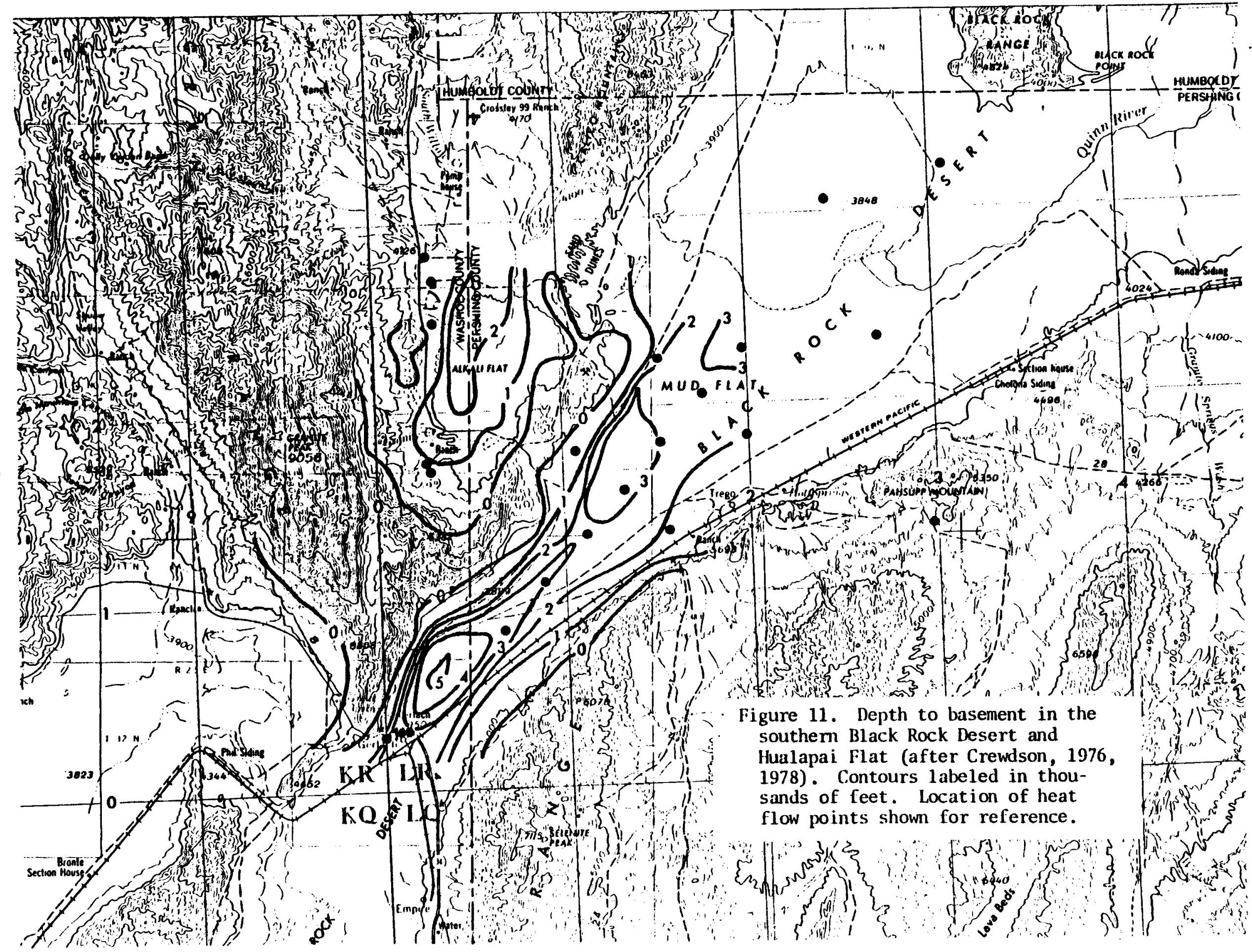


of teleseismic P-wave residuals recorded with the microearthquake net appears to preclude a local magma chamber underlying the area consistent with the lack of young volcanism. (The youngest flows are $23 \mathrm{~m} . \mathrm{y}$. in age as mentioned in the geologic setting.)

A 75-km long, north-south magnetotelluric profile transected the GerlachHualapi flat area (Zeisloft and Keller, 1978). No local anomalies associated with the surface geothermal manifestations were reported. However, on a regional scale, the results show a decrease in apparent resistivity at low frequencies (0.01-0.05 Hz), interpreted as indicating highly conductive rock at a depth of 20-25 $\mathrm{km}$. Zeisloft and Keller interpret this highly conductive zone as reflecting depth to temperatures exceeding $800^{\circ} \mathrm{C}$ probably within the uppermost mantle. This interpretation provides additional support for the inclusion of this region in the Battle Mountain heat-flow high (see e.g., Figures 9-13a and 19, Lachenbruch and Sass, 1978).

The Hualapi flat area, a region of intense late Quaternary rifting (see Grose, 1978), was the site of two local electrical surveys. One, a direct current (dc) resistivity technique called quadripole mapping, proved useful in revealing the general trend of the basement surface with the observed anomalies attributable to varying thicknesses of the highly conducting basin fill (Morris, 1978). A second electrical method, TDEM (Time Domain Electromagnetic Sounding), complemented the quadripole mapping and was effective in determining electrical conductivity to a depth of $1-2 \mathrm{~km}$ (Keller and others; 1978a). An elongate area of low resistivity (3-5 sm) was found to extend north and south from Fly Ranch hot springs. 


\section{DISCUSSION AND CONCLUSIONS}

Our interpretation of the heat flow from the southern Black Rock Desert, although poorly controlled in some areas, reveals a simple and somewhat surprising distribution of heat flow in the region. The heat-flow contours (Figure 10) may be compared with depth to basement (Figure 11, from Crewdson, 1976, 1978). It is noteworthy that the heat flow appears to be lowest in some of the deepest parts of the basin. The regions of high heat flow associated with the spring systems seem controlled in every instance by the range bounding fault. The most poorly controlled and most speculative thermal anomaly is that associated with Trego Hot Spring. Here, we have one high heat-flow value (GRL, Table 1) associated with the Holocene Black Rock fault (Dodge, 1979), but apparently no northward continuation of the anomaly. The only control south and east of Trego Hot Spring is the high value in granite at Pahsupp Mountain (Figure 10). Thus, there is considerable latitude in drawing heat-flow contours near Trego, and we might expect significant changes to our tentative interpretation with improvement in the control.

Keller and others (1978b) interpret the hydrothermal regime of the Gerlach - Fly Ranch area in terms of thermal blanketing by low conductivity sediments in a "normal" Basin and Range geothermal regime. Using chemically inferred reservoir temperatures for the spring systems and the depths of adjacent alluvial cover, they estimate a mean thermal gradient in the sediments of $140^{\circ} \mathrm{C} / \mathrm{km}$ based on the assumption that the springs are sampling aquifers near the base of the adjacent alluvial fill. Combined with our well-documented mean conductivity of $2.5 \mathrm{HCU}$ (Figure 4), this gradient would result in a regional heat flux of 3.5 HFU--a value characteristic of some of the hotter parts of the Battle Mountain high (Sass and others, 1971, 1977; Lachenbruch and Sass, 1977). According to the heat-flow data (Figure 10), the deeper 
parts of the valley (Figure 11) are quite cold. Assuming then that thermal blanketing by low conductivity sediments is playing a relatively minor role in the heating of reservoir fluids, circulation of meteoric water to depths of up to $7 \mathrm{~km}$ would be required (for a basement conductivity of $7 \mathrm{HCU}$ ) to achieve reservoir temperatures characteristic of Gerlach $\left(\sim 200^{\circ} \mathrm{C}\right)$ if regional heat flow were $2 \mathrm{HFU}$. For heat flows of 2.5 and $3 \mathrm{HFU}\left(\sim 100\right.$ and $\left.125 \mathrm{mWm}^{-2}\right)$ the corresponding temperature gradients are 36 and $43{ }^{\circ} \mathrm{C} / \mathrm{km}$ and the depths of circulation 5.6 and $4.6 \mathrm{~km}$. The microearthquake data presented in the last section suggest active, intense fracturing in the depth range $3-7 \mathrm{~km}$ indicating that channelways for this deep circulation of meteoric water probably do exist.

Outside of the areas of anomalous heat flow associated with the spring systems, the mean heat flow for 13 sites is $1.8 \pm 0.15 \mathrm{HFU}\left(75 \pm 6 \mathrm{mWm}^{-2}\right)$, somewhat lower than the mean for the Basin and Range province. This mean is of doubtful regional significance because, apart from PMS (Figure 2), we have no heat-flow data from the ranges where most of the recharge for the systems probably originates. Despite this uncertainty, it is instructive to add to the background conductive flux the combined conductive and convective discharge from the spring systems. In Table 4, we have summarized the various estimates of convective flow from different sources (see Table A-1 for details). Using a conservative multiplier of 3 (cf. Olmsted and others, 1975) for the anomalous conductive heat flow, we estimate a combined heat loss (above background) for the southern Black Rock Desert of $8.0 \mathrm{Mcal} \mathrm{s}^{-1}$ or $34 \mathrm{MW}$. If we assume that the hydrothermal flow system or systems of the southern Black Rock Desert are coextensive with the surface drainage basins, we estimate an area of roughly $1000 \mathrm{~km}^{2}$ for all of the systems. If we then distribute the anomalous $8 \mathrm{Mcal} \mathrm{s}^{-1}$ over $1000 \mathrm{~km}^{2}$, we may add $0.8 \mathrm{HFU}$ 
TABLE 4. Heat discharge of hot springs in the southern Black Rock Desert

\begin{tabular}{llc}
\hline \multicolumn{1}{c}{ Site } & $\begin{array}{c}\text { Convective heat } \\
\text { cal s } 1\end{array}$ & $\begin{array}{c}\text { loss } \\
\mathrm{MW}\end{array}$ \\
\hline Gerlach/Great Boiling Hot Springs & $1.2 \times 10^{6}$ & 5.0 \\
Double Hot and Black Rock Point & $0.19 \times 10^{6}$ & 0.8 \\
Trego & $0.09 \times 10^{6}$ & 0.4 \\
Fly Ranch & $\underline{0.56 \times 16^{6}}$ & $\underline{2.2}$ \\
\multicolumn{1}{c}{ Total } & $2.0 \times 10^{6}$ & 8.4 \\
\hline
\end{tabular}


(32 $\mathrm{mWm}^{-2}$ ) to our mean heat flow of 1.8 for sites distant from the spring systems for a mean regional heat flow of $2.5+\mathrm{HFU}\left(100+\mathrm{mWm}^{-2}\right)$. This crude analysis, while sensitive to some rather tenuous assumptions regarding the size of the system and the ratio of anomalous conductive to convective heat flux (among others) lends support to the notion that this region is indeed a part of the Battle Mountain high (Figure 1). This, in turn, suggests that the reservoir temperatures characteristic of the thermal spring systems in the region are maintained by the circulation of meteoric water within the crystalline basement to depths of from 4 to 6 kilometers. 


\section{References}

Bonham, H. F., 1969, Geology and mineral deposits of Washoe and Storey counties, Nevada: Nevada Bureau of Mines Bulletin, v. 70, 140 p.

Brook, C. A., Mariner, R. H., Mabey, D. R., Swanson, J. R., Guffanti, M., and Muffler, L. J. P., 1979, Hydrothermal convection systems with reservoir temperatures $90^{\circ} \mathrm{C}$, in Assessment of Geothermal Resources of the United States, 1978, edited by L. J. P. Muffler: U.S. Geological Survey Circular 790 , p. 18-85.

Callaway, J., 1978, Reflection seismic traverse across Black Rock Desert and Hualapi Flat, Nevada: Colorado School of Mines Quarterly, v. 73, no. 3, p. $65-72$.

Crewdson, R. A., 1976, Geophysical studies in the Black Rock Desert geothermal prospect: Ph.D. thesis, Colorado School of Mines, Golden, Colorado, $180 \mathrm{p}$.

Crewdson, R. A., 1978, A gravity survey of Hualapi Flat and the southern part of the Black Rock Desert, Nevada: Colorado School of Mines Quarterly, v. 73 , no. 3, p. 73-84.

Dodge, R. L., and Grose, L. T., 1979, Seismotectonic and geomorphic evolution of a typical Basin and Range normal fault, the Holocene Black Rock fault, northwestern Nevada: Geological Society of America, Abstracts with Programs, v. 11, no. 3, p. 75.

Grose, L. T., 1978, Late Quaternary tectonic controls of occurrence of geothermal systems in Gerlach-Hualapi Flat area, northwestern Nevada: Colorado School of Mines Quarterly, v. 73, no. 3, p. 11-14.

Grose, L. T., and Sperandio, R. J., 1978, Geology of the GerlachHualapi Flat geothermal area, northwestern Nevada: Colorado School of Mines Quarterly, จ. 73, no. 3, p. 1-10. 
Keller, G. V., Crewdson, R. A., Daniels, J. J., 1978a, Time-domain electromagnetic survey in Black Rock Desert-Hualapi Flat area of northwestern Nevada: Colorado School of Mines Quarterly, v. 73, no. 4, p. 47-56.

Keller, G. V., Grose, L. T., and Crewdson, R. A., 1978b, Speculations on nature of geothermal energy in Basin and Range province of western United States: Colorado School of Mines Quarterly, v. 73, no. 4, p. 71-76. Kumamoto, L., 1978, Microearthquake survey in the Gerlach-Fly Ranch area of northwestern Nevada: Colorado School of Mines Quarterly, v. 73, no. 3, p. $45-64$.

Lachenbruch, A. H., Sorey, M. L., Lewis, R. E., and Sass, J. H., 1976, The near-surface hydrothermal regime of Long Valley caldera: Journal of Geophysical Research, v. 81, p. 763-768.

Lachenbruch, A. H., and Sass, J. H., 1977, Heat flow in the United States and the thermal regime of the crust, in The Earth's Crust, edited by J. G. Heacock: American Geophysical Union Geophysical Monograph 20, p. 626-675.

Lachenbruch, A. H., and Sass, J. H., 1978, Models of an extending lithosphere and heat flow in the Basin and Range province: Geological Society of America Memoir 152, p. 209-250.

Morris, D., 1978, A quadripole resistivity survey north of Gerlach, Nevada: Colorado School of Mines Quarterly, v. 73, no. 4, p. 1-18.

Muffler, L. J. P. (editor), 1979, Assessment of geothermal resources of the United States - 1978: U.S. Geological Survey Circular 790, 163 p.

Olmsted, F. H., Glancy, P. A., Harrill, J. R., Rush, F. E., and Van Denburgh, A. S., 1975, Preliminary hydrogeologic appraisal of selected hydrothermal systems in northern. and central Nevada: U.S. Geological Survey Open-File Report 75-56, 267 p. 
Renner, J. L., White, D. E., and Williams, D. L., 1975, Hydrothermal convection systems, in Assessment of Geothermal Resources of the United States, 1975, edited by D. E. White and D. L. Williams: U.S. Geological Survey Circular 726, p. 5-57.

Sass, J. H., Lachenbruch, A. H., Munroe, R. J., Greene, G. W., and Moses, T. H., Jr., 1971, Heat flow in the western United States: Journal of Geophysical Research, v. 76, p. 6376-6413.

Sass. J. H., Ziagos, J. P., Wollenberg, H. A., Munroe, R. J., diSomma, D. E., and Lachenbruch, A. H., 1977, Application of heat-flow techniques to geothermal energy exploration, Leach Hot Springs area, Grass Valley, Nevada: U.S. Geological Survey Open-File Report 76-762.

Sass, J. H., Kennelly, J. P., Jr., Wendt, W. E., Moses, T. H., Jr., and Ziagos, J. P., 1979, In situ determination of heat flow in unconsolidated sediments: U.S. Geological Survey Open-File Report 79-593.

Waring, G. A., 1975, Thermal springs of the United States and other countries of the world: U.S. Geological Survey Professional Paper 492.

Willden, R., 1964, Geology and mineral deposits of Humboldt County, Nevada: Nevada Bureau of Mines Bulletin, v. 59, 154 p.

Zeisloft, T. J., and Keller, G. V., 1978, Magnetotelluric survey across Black Rock Desert-Hualapi Flat area, Nevada: Colorado School of Mines Quarterly, v. 73, no. 4, p. 39-46.

Zoback, Mary Lou, and Thompson, G. A., 1978, Basin and Range rifting in northern Nevada--Clues from a mid-Miocene rift and its subsequent offsets: Geology, $\nabla .6$, p. 111-116. 


\section{APPENDIX}

Temperature profiles and some details of the spring discharge calculations Individual temperature profiles for most wells in the Black Rock Desert are presented in Appendix A of Sass and others (1979). Profiles not included in that paper are presented in this Appendix. Also included in this Appendix is a breakdown of individual discharge and temperature estimates and their sources, used in the compilation of Table 4. 


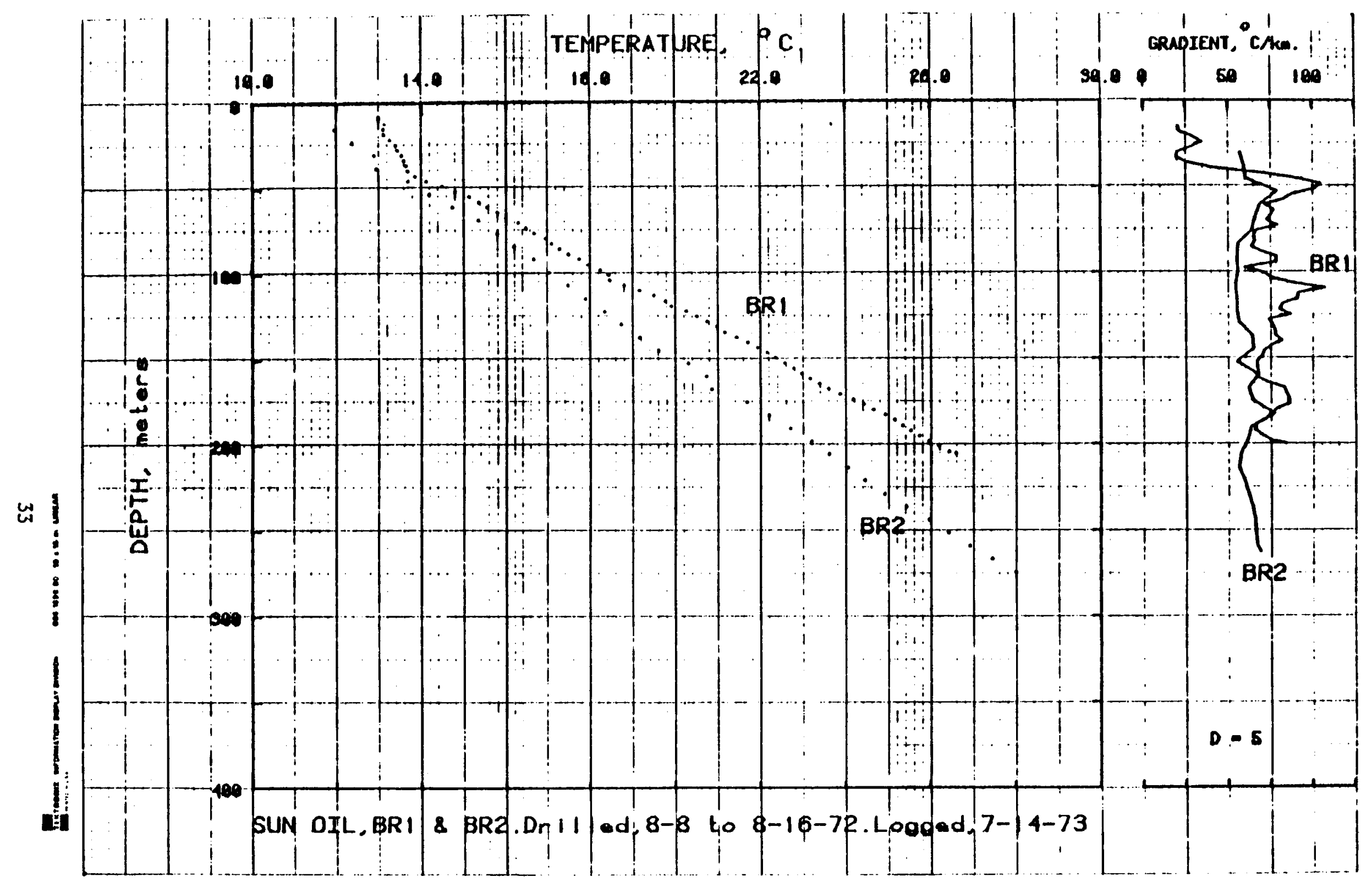

Figure Al. 


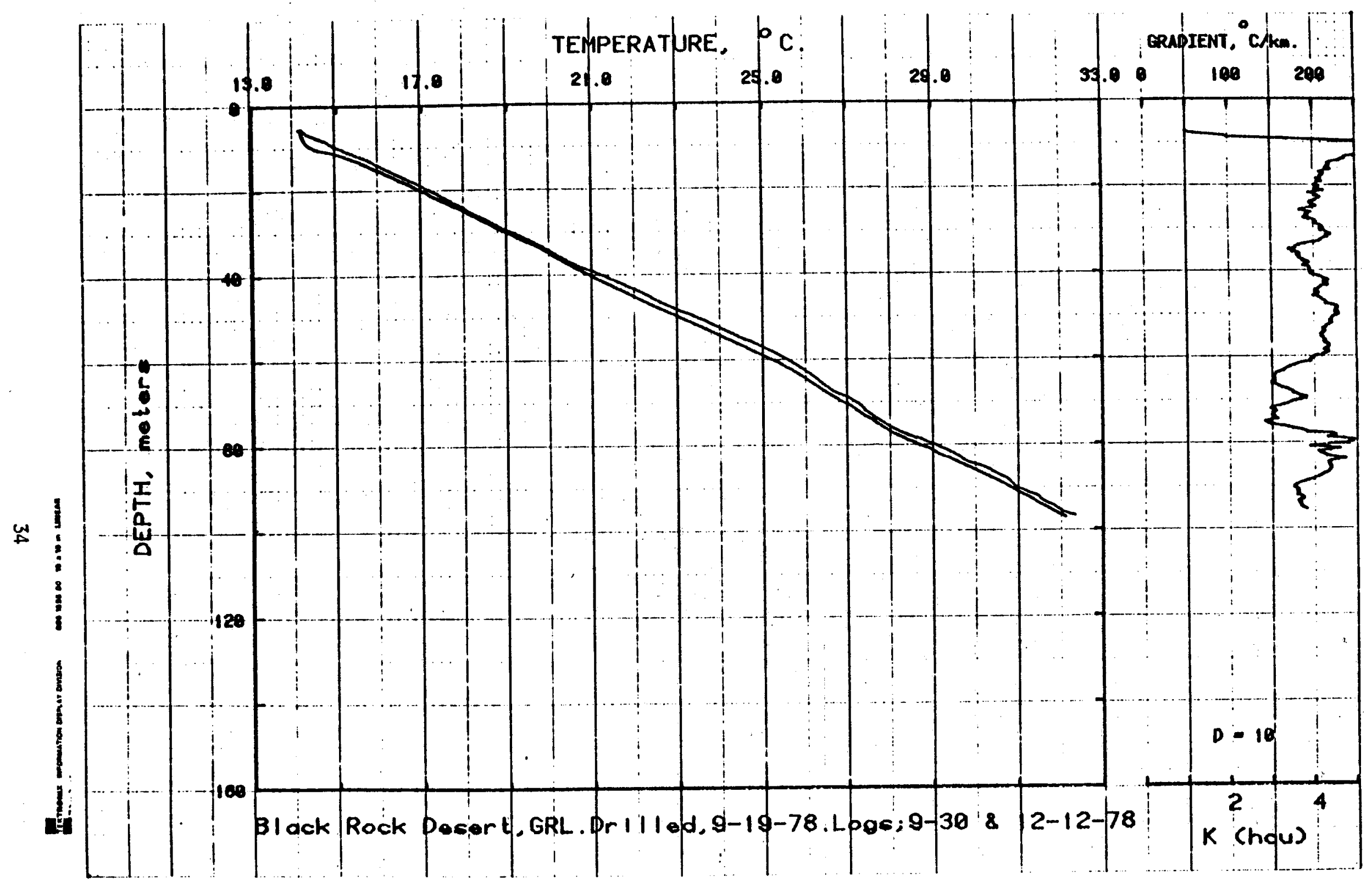

Figure $\mathbf{A} 2$. 


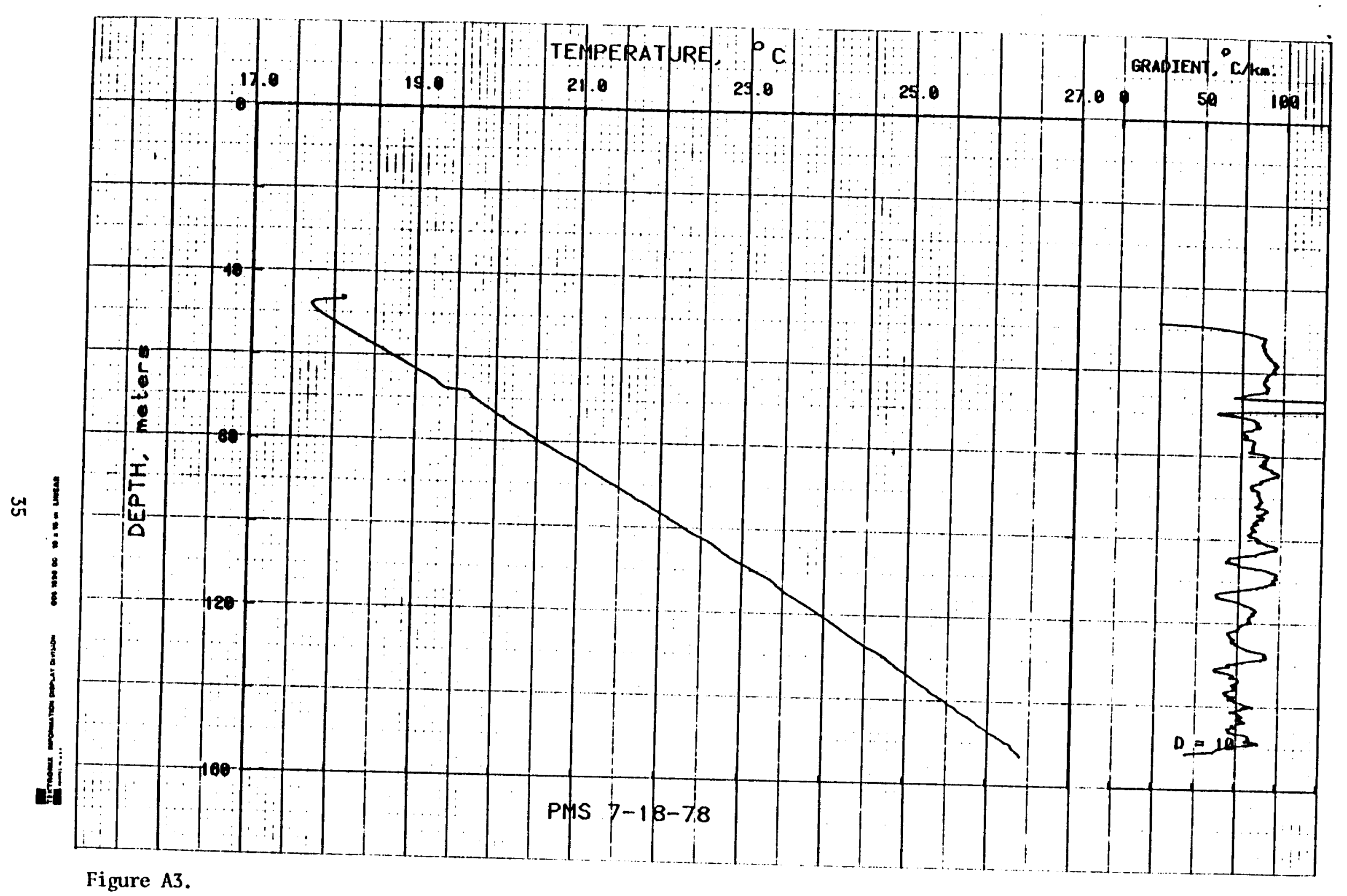




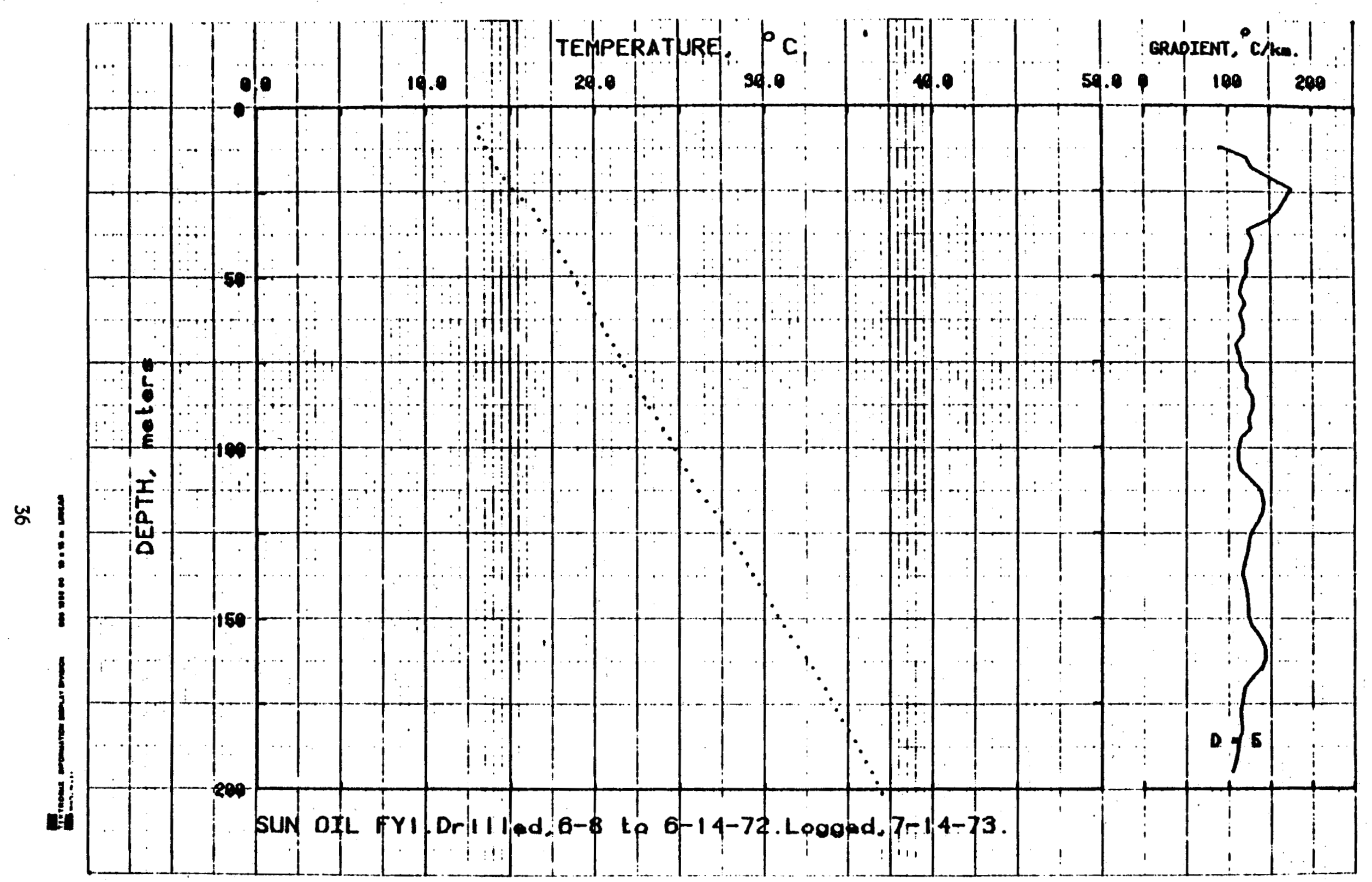

Figure A4. 


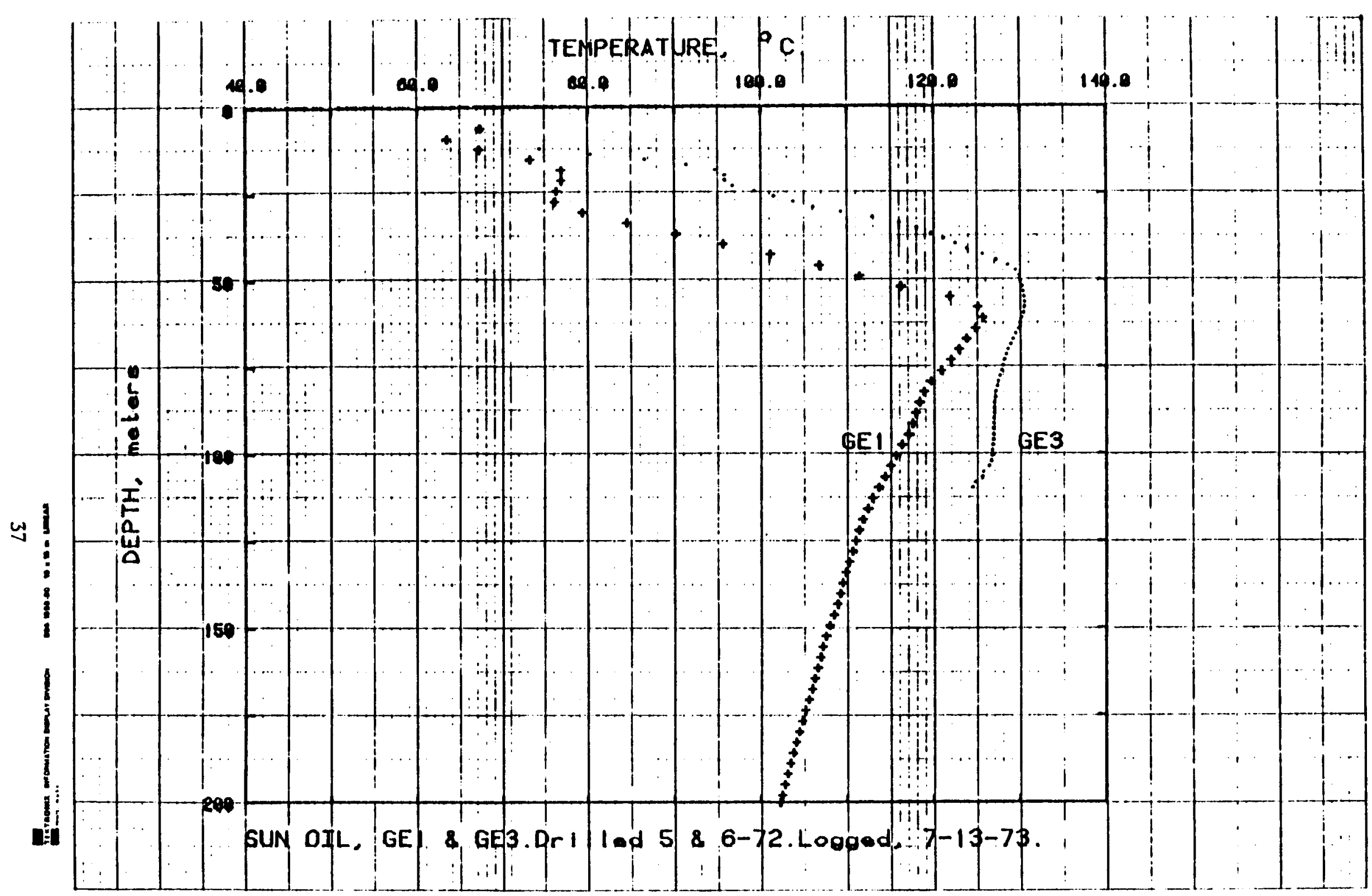

Figure A5. 


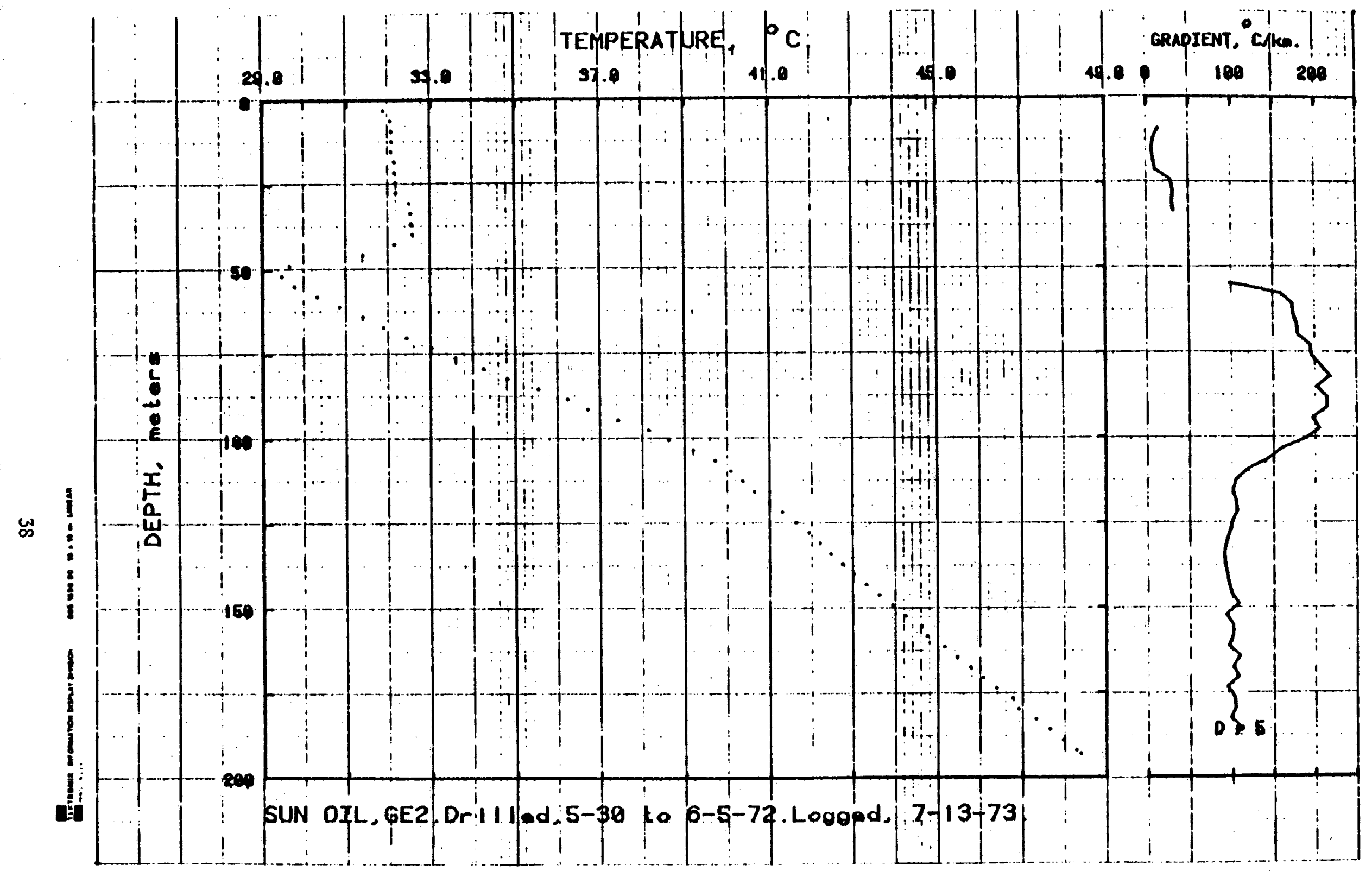

Figure A6. 
TABLI: A-1. Estimates of spring discharge from the southern Black Rock Desert

\begin{tabular}{|c|c|c|c|c|c|}
\hline Site & Reference & $\begin{array}{l}\text { Surface } \\
\text { Temp. }\left(T_{S}\right)\end{array}$ & $\begin{array}{l}\text { Discharge } \\
\text { (L/m) }\end{array}$ & $\Delta T=T_{S}-T_{m}^{*}$ & $\begin{array}{l}\text { theat discharge } \\
\rho \cdot \Delta \mathrm{T} \cdot[\text { [nischarge] } \\
\text { (cal/sec) }\end{array}$ \\
\hline \multirow{2}{*}{$\begin{array}{l}\text { Cerlach area (overall average) } \\
\text { Great Boilling Springs } \\
\text { Borax Works } \\
119 \\
168\end{array}$} & Olmsted and others, 1975 & $80^{\circ}$ & 1000 & $69^{\circ}$ & $1.2 \times 10^{6}$ \\
\hline & $\begin{array}{l}\text { Olmsted and others, } 1975 \\
\text { Olmsted and others, } 1975\end{array}$ & $\begin{array}{l}96^{\circ} \\
58^{\circ}\end{array}$ & $\begin{array}{r}15 \\
210\end{array}$ & $\begin{array}{l}85^{\circ} \\
47^{\circ}\end{array}$ & $\begin{array}{l}2.1 \times 10^{4} \\
1.6 \times 10^{5}\end{array}$ \\
\hline Bathing Springs & Olmsted and others, 1975 & $90^{\circ}$ & 355 & $79^{\circ}$ & $4.5 \times 10^{5}$ \\
\hline Miscellaneous small springs & Olmsted and others, 1975 & $\begin{array}{l}54^{\circ} \\
96^{\circ} \\
68^{\circ} \\
49^{\circ}\end{array}$ & $\begin{array}{l}11.5 \\
60 \\
85 \\
4\end{array}$ & $\begin{array}{l}43^{\circ} \\
85^{\circ} \\
57^{\circ} \\
38^{\circ}\end{array}$ & $\begin{array}{l}7.9 \times 10^{3} \\
8.3 \times 10^{4} \\
7.7 \times 10^{4} \\
2.2 \times 10^{3}\end{array}$ \\
\hline Mud Springs & Olnsted and others, 1975 & $75^{\circ}$ & 335 & $64^{\circ}$ & $3.6 \times 10^{5}$ \\
\hline Double Ibt and Black Rock Point area & Renner and others, 1975 & $80^{\circ}$ & 175 & $69^{\circ}$ & $2.0 \times 10^{5}$ \\
\hline Trego (Butte) lbt Springs & Waring, 1965 & $84^{\circ}$ & 75 & $73^{\circ}$ & $9.0 \times 10^{4}$ \\
\hline Fly Ranch Ibt Springs & Brook and others, 1979 & $80^{\circ}$ & 500 & $69^{\circ}$ & $5.6 \times 10^{5}$ \\
\hline
\end{tabular}

Mean ansual temperature $=11^{\circ} \mathrm{C}$.

$t_{\rho}=$ Density $=.97 \times 10^{6} \mathrm{~g} / \mathrm{m}^{3}$. 